Prepared in cooperation with the Harris-Galveston Subsidence District, City of Houston, Fort Bend Subsidence District, Lone Star Groundwater Conservation District, and Brazoria County Groundwater Conservation District

\title{
Water-Level Altitudes 2012 and Water-Level Changes in the Chicot, Evangeline, and Jasper Aquifers and Compaction 1973-2011 in the Chicot and Evangeline Aquifers, Houston-Galveston Region, Texas
}

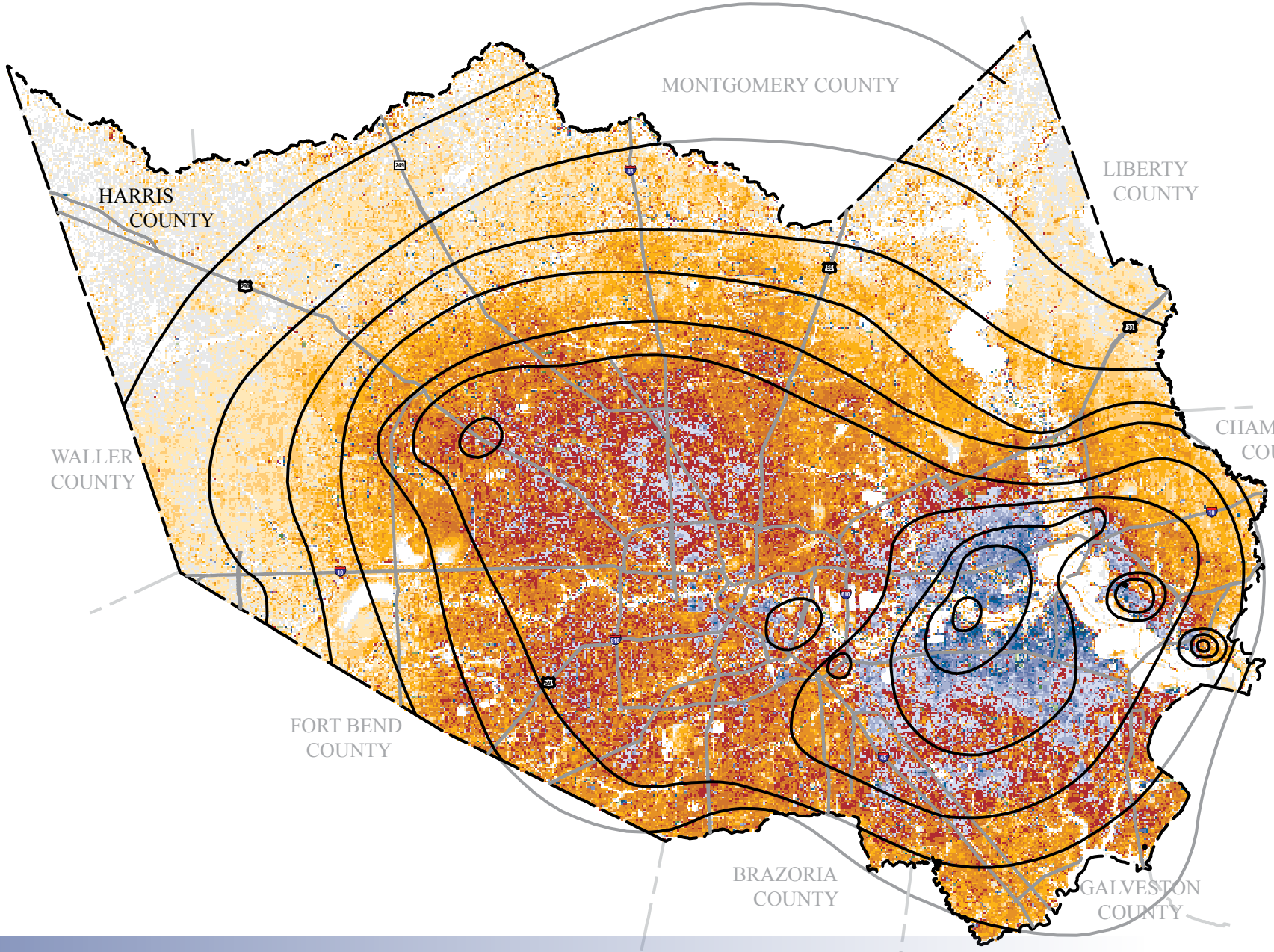

Scientific Investigations Map 3230 


\section{Back cover:}

Left, Water well slab and casing protruding above land surface because of land-surface subsidence,

Baytown, Texas, area, September 2004.

Right, Typical borehole extensometer shelter, Addicks, Texas, May 2008. 


\section{Water-Level Altitudes 2012 and Water- Level Changes in the Chicot, Evangeline, and Jasper Aquifers and Compaction 1973- 2011 in the Chicot and Evangeline Aquifers, Houston-Galveston Region, Texas}

By Mark C. Kasmarek, Michaela R. Johnson, and Jason K. Ramage

Prepared in cooperation with the Harris-Galveston Subsidence District,

City of Houston, Fort Bend Subsidence District,

Lone Star Groundwater Conservation District, and

Brazoria County Groundwater Conservation District

Scientific Investigations Map 3230 


\title{
U.S. Department of the Interior \\ KEN SALAZAR, Secretary \\ U.S. Geological Survey \\ Marcia K. McNutt, Director
}

\section{U.S. Geological Survey, Reston, Virginia: 2012}

\author{
This and other USGS information products are available at http://store.usgs.gov/ \\ U.S. Geological Survey \\ Box 25286, Denver Federal Center \\ Denver, CO 80225 \\ To learn about the USGS and its information products visit http://www.usgs.gov/ \\ 1-888-ASK-USGS
}

\footnotetext{
Any use of trade, product, or firm names is for descriptive purposes only and does not imply endorsement by the U.S. Government.

Although this report is in the public domain, permission must be secured from the individual copyright owners to reproduce any copyrighted materials contained within this report.
}

Suggested citation:

Kasmarek, M.C., Johnson, M.R., and Ramage, J.K., 2012, Water-level altitudes 2012 and water-level changes in the Chicot, Evangeline, and Jasper aquifers and compaction 1973-2011 in the Chicot and Evangeline aquifers, HoustonGalveston region, Texas: U.S. Geological Survey Scientific Investigations Map 3230, 18 p., 16 sheets. 


\section{Acknowledgments}

The authors thank the owners and operators of wells throughout the study area for graciously granting access to wells and providing pertinent information, and additionally, the cooperation of the Harris-Galveston Subsidence District, City of Houston, Fort Bend Subsidence District, Lone Star Groundwater Conservation District, and Brazoria County Groundwater Conservation District. 



\section{Contents}

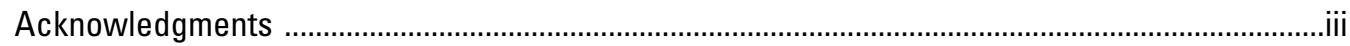

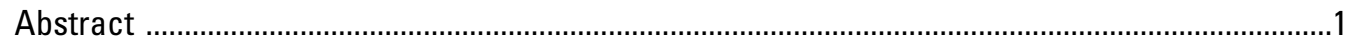

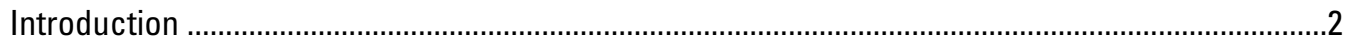

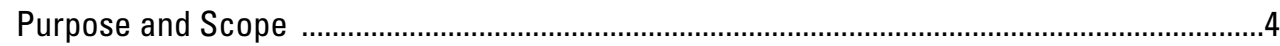

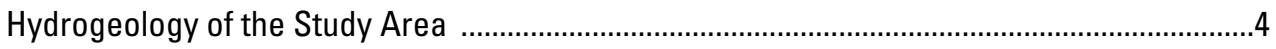

Subsidence and Compaction Processes ..............................................................................8

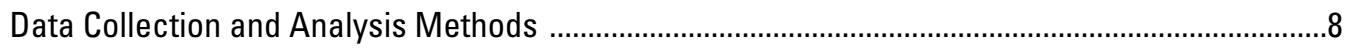

Determination of Water-Level Altitudes ................................................................................

Depicting Changes in Water-Level Altitudes ...........................................................................

Borehole Extensometers .................................................................................................... 10

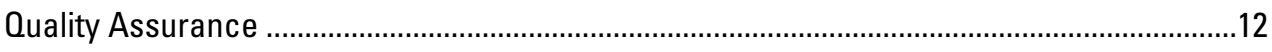

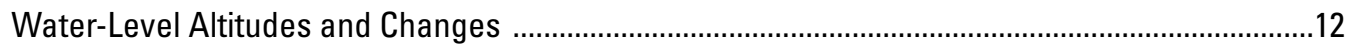

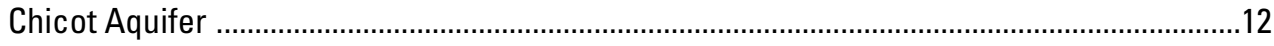

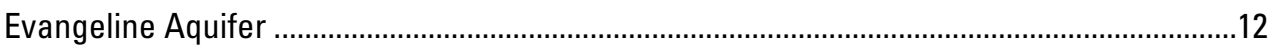

Jasper Aquifer .......................................................................................................................... 13

Compaction in the Chicot and Evangeline Aquifers ................................................................13

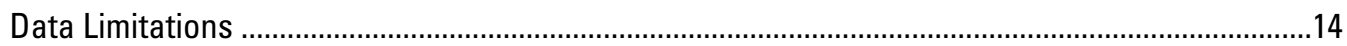

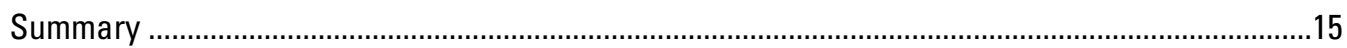

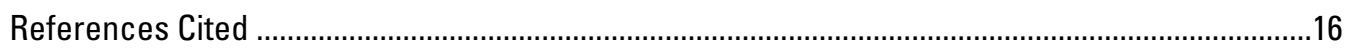

Appendix 1. Well location maps

(Available online at http://pubs.usgs.gov/sim/3230/.)

1.1. Map showing location of wells screened in the Chicot aquifer, HoustonGalveston region, Texas.

1.2. Map showing location of wells screened in the Evangeline aquifer, HoustonGalveston region, Texas.

1.3. Map showing location of wells screened in the Jasper aquifer, HoustonGalveston region, Texas.

\section{Sheets}

(Available online at http://pubs.usgs.gov/sim/3230/.)

1. Map showing approximate 2012 water-level altitudes in the Chicot aquifer, Houston-Galveston region, Texas, water-level- measurement data collected during December 2011-February 2012

2. Map showing water-level changes in the Chicot aquifer, Houston-Galveston region, Texas, 2011-12

3. Map showing approximate water-level changes in the Chicot aquifer, HoustonGalveston region, Texas, 2007-12

4. Map showing approximate water-level changes in the Chicot aquifer, HoustonGalveston region, Texas, 1990-2012

5. Map showing approximate water-level changes in the Chicot aquifer, HoustonGalveston region, Texas, 1977-2012 
6. Map showing approximate 2012 water-level altitudes in the Evangeline aquifer, Houston-Galveston region, Texas, water-level-measurement data collected during December 2011-February 2012

7. Map showing water-level changes in the Evangeline aquifer, Houston-Galveston region, Texas, 2011-12

8. Map showing approximate water-level changes in the Evangeline aquifer, HoustonGalveston region, Texas, 2007-12

9. Map showing approximate water-level changes in the Evangeline aquifer, HoustonGalveston region, Texas, 1990-2012

10. Map showing approximate water-level changes in the Evangeline aquifer, HoustonGalveston region, Texas, 1977-2012

11. Map showing approximate 2012 water-level altitudes in the Jasper aquifer, Houston-Galveston region, Texas, water-level-measurement data collected during December 2011-February 2012

12. Map showing water-level changes in the Jasper aquifer, Houston-Galveston region, Texas, 2011-12

13. Map showing approximate water-level changes in the Jasper aquifer, HoustonGalveston region, Texas, 2007-12

14. Map showing approximate water-level changes in the Jasper aquifer, HoustonGalveston region, Texas, 2000-2012

15. Map showing location of borehole-extensometer sites, Houston-Galveston region, Texas

16. Graphs showing measured compaction of subsurface sediments, 1973-2011, at borehole-extensometer-site locations shown on sheet 15, in the HoustonGalveston region, Texas

\section{Figures}

1. Map showing locations of groundwater-regulatory districts and the HoustonGalveston region study area, Texas .

2. Hydrogeologic section of the Gulf Coast aquifer system in Harris County and adjacent counties, Texas

3. Hydrogeologic section of the Gulf Coast aquifer system in Fort Bend County, Texas .....6

4. Hydrogeologic section of the Gulf Coast aquifer system in Waller, Harris, Montgomery, San Jacinto, Polk, Tyler, Jasper, and Newton Counties, Texas

5. Diagram depicting the mechanism of subsidence in an aquifer composed of sand, gravel, clay, and silt

6. Diagram depicting cross-sectional perspective of the borehole extensometer/ piezometer (LJ-65-23-322) located at Pasadena, Texas 


\section{Tables}

(Available online at http://pubs.usgs.gov/sim/3230/.)

1. Data for the Chicot aquifer sheets 1, 2, 3, 4, and 5: (1) approximate 2012 waterlevel altitudes, water-level data collected during December 2011-February 2012; (2) water-level changes 2011-12; (3) approximate water-level changes 2007-12;

(4) approximate water-level changes 1990-2012; and (5) approximate water-level changes 1977-2012 in the Houston-Galveston region,Texas

2. Data for the Evangeline aquifer sheets 6, 7, 8, 9, and 10: (6) approximate 2012 water-level altitudes, water-level data collected during December 2011-February 2012; (7) water-level changes 2011-12; (8) approximate water-level changes 2007-12; (9) approximate water-level changes 1990-2012; and (10) approximate water-level changes 1977-2012 in the Houston-Galveston region,Texas

3. Data for the Jasper aquifer sheets 11, 12, 13, and 14: (11) approximate 2012 waterlevel altitudes, water-level data collected during December 2011-February 2012;

(12) water-level changes 2011-12; (13) approximate water-level changes 2007-12; and (14) approximate water-level changes 2000-12 in the Houston-Galveston region, Texas

4. Data for sheet 16, measured compaction of subsurface sediments, 1973-2011, at borehole-extensometer-site locations shown on figure 15, in the HoustonGalveston region, Texas

\section{Conversion Factors and Datums}

\section{Inch/Pound to SI}

\begin{tabular}{|c|c|c|}
\hline Multiply & By & To obtain \\
\hline \multicolumn{3}{|c|}{ Length } \\
\hline inch (in) & 2.54 & centimeter $(\mathrm{cm})$ \\
\hline inch (in) & 25.4 & millimeter $(\mathrm{mm})$ \\
\hline foot $(\mathrm{ft})$ & 0.3048 & meter $(\mathrm{m})$ \\
\hline mile (mi) & 1.609 & kilometer $(\mathrm{km})$ \\
\hline \multicolumn{3}{|c|}{ Area } \\
\hline acre & 4,047 & square meter $\left(\mathrm{m}^{2}\right)$ \\
\hline square foot $\left(\mathrm{ft}^{2}\right)$ & 0.09290 & square meter $\left(\mathrm{m}^{2}\right)$ \\
\hline square mile $\left(\mathrm{mi}^{2}\right)$ & 2.590 & square kilometer $\left(\mathrm{km}^{2}\right)$ \\
\hline
\end{tabular}

Vertical coordinate information is referenced to the National Geodetic Vertical Datum of 1929 (NGVD 29) or the North American Vertical Datum of 1988 (NAVD 88).

Horizontal coordinate information is referenced to the North American Datum of 1927 (NAD 27). 



\title{
Water-Level Altitudes 2012 and Water-Level Changes in the Chicot, Evangeline, and Jasper Aquifers and Compaction 1973-2011 in the Chicot and Evangeline Aquifers, Houston-Galveston Region, Texas
}

\author{
By Mark C. Kasmarek, Michaela R. Johnson, and Jason K. Ramage
}

\begin{abstract}
Most of the subsidence in the Houston-Galveston region, Texas, has occurred as a direct result of groundwater withdrawals for municipal supply, commercial and industrial use, and irrigation that depressured and dewatered the Chicot and Evangeline aquifers and caused compaction of the clay layers of the aquifer sediments. This report-prepared by the U.S. Geological Survey in cooperation with the HarrisGalveston Subsidence District, City of Houston, Fort Bend Subsidence District, Lone Star Groundwater Conservation District, and Brazoria County Groundwater Conservation District - is one in an annual series of reports depicting water-level altitudes and water-level changes in the Chicot, Evangeline, and Jasper aquifers and compaction in the Chicot and Evangeline aquifers in the Houston-Galveston region. The report contains maps showing approximate water-level altitudes for 2012 (calculated from measurements of water levels in wells made during December 2011-February 2012) for the Chicot, Evangeline, and Jasper aquifers; maps showing 1-year (2011-12) water-level-altitude changes for each aquifer; maps showing 5-year (2007-12) water-levelaltitude changes for each aquifer; maps showing long-term (1990-2012 and 1977-2012) water-level-altitude changes for the Chicot and Evangeline aquifers; a map showing long-term (2000-12) water-level-altitude change for the Jasper aquifer; a map showing locations of borehole extensometer sites; and graphs showing measured compaction of subsurface sediments at the extensometers from 1973 (or later) through 2011. Tables listing the data that were used to construct each water-level map for each aquifer and the cumulative compaction graphs are included.

In 2012, water-level-altitude contours for the Chicot aquifer ranged from 250 feet (ft) below North American Vertical Datum of 1988 (hereinafter, datum) in a small area in southwestern Harris County to $200 \mathrm{ft}$ above datum in westerncentral Montgomery County. Water-level-altitude changes during 2012 in the Chicot aquifer ranged from a 48-ft decline
\end{abstract}

to an 18-ft rise. Contoured 5-year and long-term changes in water-level altitudes in the Chicot aquifer ranged from a $60-\mathrm{ft}$ decline to a $40-\mathrm{ft}$ rise (2007-12), from a 100-ft decline to an $80-\mathrm{ft}$ rise (1990-2012), and from a $100-\mathrm{ft}$ decline to a $200-\mathrm{ft}$ rise (1977-2012). In 2012, water-level-altitude contours for the Evangeline aquifer ranged from $300 \mathrm{ft}$ below datum in isolated areas located in south-central Montgomery County and north-central Harris County, in southwest Harris County, and in northeastern Fort Bend County to $200 \mathrm{ft}$ above datum near the county boundary intersection of Waller, Montgomery, and Grimes Counties. Water-level-altitude changes for 2012 in the Evangeline aquifer ranged from a $90-\mathrm{ft}$ decline to a 39 -ft rise. Contoured 5-year and long-term changes in waterlevel altitudes in the Evangeline aquifer ranged from an $80-\mathrm{ft}$ decline to an $80-\mathrm{ft}$ rise (2007-12), from a 220 -ft decline to a $220-\mathrm{ft}$ rise (1990-2012), and from a 360-ft decline to a 260 -ft rise (1977-2012). In 2012, water-level-altitude contours for the Jasper aquifer ranged from $250 \mathrm{ft}$ below datum in south-central Montgomery County to $250 \mathrm{ft}$ above datum in northwest Montgomery County. Water-level-altitude changes for 2012 in the Jasper aquifer ranged from a 74-ft decline to a 4-ft rise. Contoured changes in water-level altitudes in the Jasper aquifer ranged from a $120-\mathrm{ft}$ decline to no change (2007-12), and from a 220-ft decline to no change (2000-12).

Compaction of subsurface sediments (mostly in the clay layers) composing the Chicot and Evangeline aquifers was recorded continuously at 13 borehole extensometers at 11 sites. For the period of record beginning in 1973 (or later) and ending in December 2011, cumulative compaction data collected from the 13 extensometers ranged from $0.102 \mathrm{ft}$ at the Texas City-Moses Lake site to $3.621 \mathrm{ft}$ at the Addicks site. The rate of compaction varies from site to site because of differences in groundwater withdrawals near each site and differences among sites in the clay-to-sand ratio in the subsurface sediments. Therefore, it is not possible to extrapolate or infer a rate of compaction for adjacent areas on the basis of the rate of compaction measured at a nearby extensometer. 


\section{Introduction}

The Houston-Galveston region-comprising Harris, Galveston, Fort Bend, Montgomery, Brazoria, Chambers, Liberty, San Jacinto, Walker, Grimes, Waller, and Chambers Counties (fig. 1) - represents one of the largest areas of subsidence in the United States (Coplin and Galloway, 1999). Allen (1969) described ground surface displacement (landsurface subsidence) as the last step of a variety of subsurface displacement mechanisms that included (among others) compaction of sediments by loading, drainage, vibration, and hydrocompaction. "By 1979, as much as 10 feet (ft) of subsidence had occurred in the Houston-Galveston region, and approximately 3,200-square miles $\left(\mathrm{mi}^{2}\right)$ of the $11,000-\mathrm{mi}^{2}$ geographic area had subsided more than $1 \mathrm{ft}$ " (Coplin and Galloway, 1999, p. 40). Comparing land-surface altitudes for 1915-17 to those for 2001, Kasmarek, Gabrysch, and Johnson (2010, sheet 2) determined that as much as $13 \mathrm{ft}$ of subsidence has occurred in southeastern Harris County.

Groundwater withdrawn from the Chicot, Evangeline, and Jasper aquifers has been the primary source of water for municipal supply, industrial and commercial use, and irrigation in the Houston-Galveston region since the early 1900s (Kasmarek and Robinson, 2004). Land-surface subsidence caused by fluid withdrawals was first documented in the Houston area in conjunction with the Goose Creek oil field in southeastern Harris County (Pratt and Johnson, 1926). Most of the subsidence in the Houston-Galveston region has occurred as a direct result of groundwater withdrawals that have depressured and dewatered the Chicot and Evangeline aquifers, thereby causing compaction of the clay layers of the aquifer sediments (Winslow and Doyle, 1954; Winslow and Wood, 1959; Gabrysch and Bonnet, 1975; Gabrysch, 1984; Holzer and Bluntzer, 1984; Kasmarek, Gabrysch, and Johnson, 2010).

Subsidence is of particular concern in low-lying coastal areas such as the Houston-Galveston region. Land subsidence in the region has increased the frequency and severity of flooding (Coplin and Galloway, 1999). Low-pressure weather systems such as tropical storms and hurricanes (National Oceanic and Atmospheric Administration, 2012) cause high tides and high rates of precipitation, and subsidence exacerbates the effects of storm surge and impedes stormwater runoff by creating areas of low land-surface elevations where water accumulates. Subsidence has shifted the coastline along Galveston Bay (fig. 1) and parts of other areas in the Houston-Galveston region, thereby changing the distribution of wetlands and aquatic vegetation (Coplin and Galloway, 1999). To address the issue of subsidence and its consequences, the 64th Texas State Legislature in 1975 authorized the establishment of the Harris-Galveston Subsidence District (HGSD) (fig. 1) to regulate and reduce groundwater withdrawals that contribute to flooding in Harris and Galveston Counties (Harris-Galveston Subsidence District, 2010). In cooperation with the HGSD, the U.S.
Geological Survey (USGS) has monitored water levels in the Chicot and Evangeline aquifers and clay compaction in Harris and Galveston Counties since 1976. The USGS has published annual reports of water-level altitudes and water-level changes for the Chicot and Evangeline aquifers in the HoustonGalveston region beginning with the 1977 water-level altitudes and annual reports of the same for the Fort Bend subregion (encompassing Fort Bend County and adjacent areas) beginning in 1990. The USGS published its first annual reports of water-level altitudes and water-level changes for the Jasper aquifer in the greater Houston area (primarily Montgomery County) beginning in 2000. Compaction data from a network of 13 borehole extensometers in the HoustonGalveston region has been presented in USGS reports of annual water-level altitudes and water-level changes since 1981 (compaction for 1973-81) and periodically has been reported on separately by USGS authors since 1954 (for example, Winslow and Doyle, 1954; Gabrysch, 1984). The previous USGS report showing depictions of water-level conditions for 2011 and coincident compaction data are presented in Johnson and others (2011).

Subsequent to establishing the HGSD, the Texas State Legislature established an additional subsidence district (Fort Bend Subsidence District [FBSD]) and two groundwater conservation districts (Lone Star Groundwater Conservation District [LSGCD] and [most recently] Brazoria County Groundwater Conservation District [BCGCD]) in the Houston-Galveston region to provide for the regulation of groundwater withdrawals in areas within their jurisdiction. The FBSD was established by the 71st Texas State Legislature in 1989 and has jurisdiction throughout Fort Bend County (fig. 1). The FBSD is divided into area A, which includes the Richmond-Rosenberg subarea, and area B. The primary purpose of the FBSD is to regulate groundwater withdrawal to prevent subsidence that contributes to flooding (Fort Bend Subsidence District, 2009). The LSGCD was established by the 77th Texas State Legislature in 2001 and has jurisdiction throughout Montgomery County (fig. 1). The purpose of the LSGCD is to conserve, protect, and enhance the groundwater resources of Montgomery County (Lone Star Groundwater Conservation District, 2011). The BCGCD was created by the 78th Texas State Legislature in 2003 with the purpose to "maintain the quality and availability of the county's groundwater resource for current users and future generations" (Brazoria County Groundwater Conservation District, 2008). Regulatory plans to gradually decrease groundwater withdrawals by increased usage of surface-water supplies are being phased in; the historical, current (2012), and future groundwater management plans of each district are available on their respective Web sites (Brazoria County Groundwater Conservation District, 2008; Fort Bend Subsidence District, 2009; Harris-Galveston Subsidence District, 2010; Lone Star Groundwater Conservation District, 2011). Presently (2012), groundwater withdrawals are not being regulated by a groundwater conservation district in Liberty and Chambers Counties. 


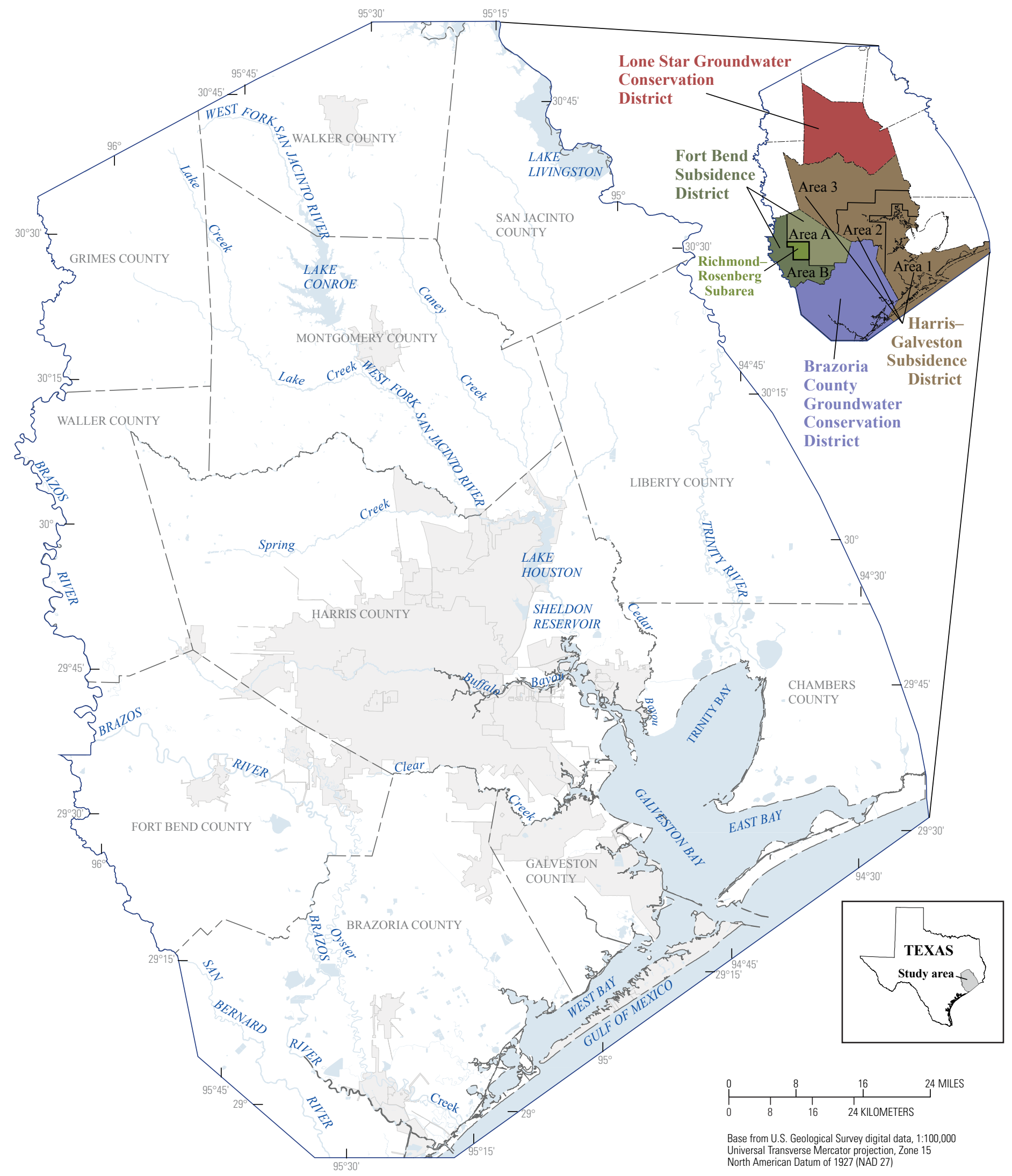

Figure 1. Locations of groundwater-regulatory districts and the Houston-Galveston region study area, Texas. 
Water-Level Altitudes 2012 and Water-Level Changes and Compaction 1973-2011, Houston-Galveston Region, Texas

In 1976 the HGSD began implementing its first groundwater regulatory plan (Harris-Galveston Subsidence District, 2010). An extensive well-monitoring network was established by 1977 , and water-level data were collected and used to create the first published water-level-altitude maps of the Chicot and Evangeline aquifers in the Houston-Galveston area (Gabrysch, 1979). The FBSD adopted its groundwater management plan in 1990 (Fort Bend Subsidence District, 2009), and in cooperation with the FBSD, an increased number of water wells were inventoried by the USGS in Fort Bend, Harris, Brazoria, and Waller Counties in 1989 and 1990. A more comprehensive water-level-altitude report for the Chicot and Evangeline aquifers was published by USGS in 1991 (Barbie and others, 1991), and when updated well data became available, the previous water-level-altitude report (Barbie and others, 1991) was revised in 1997 (Kasmarek, 1997). Similarly, after the creation of the LSGCD in 2001, the USGS first published a water-level-altitude map for the Jasper aquifer in the Houston area (primarily Montgomery County) (Coplin, 2001). In 2004, 2006, and again in 2007, as additional well data with reliable water-level-measurement data were inventoried, revised water-level-altitude maps for the Jasper aquifer were prepared (Kasmarek and Lanning-Rush, 2004; Kasmarek, Houston, and Brown, 2006; and finally, Kasmarek and Houston, 2007). In comparison to the 2001 (Coplin, 2001) and 2004 (Kasmarek and Lanning-Rush, 2004) map report versions, the 2007 version of the water-level-altitude map is the most comprehensive for the Jasper aquifer in the study area (Kasmarek and Houston, 2007).

\section{Purpose and Scope}

This report is one in an annual series of reports that depict water-level altitudes and water-level changes in the Chicot, Evangeline, and Jasper aquifers and compaction in the Chicot and Evangeline aquifers in the Houston-Galveston region. The report also describes the hydrogeology of the study area and provides an overview of the mechanism of compaction and land-surface subsidence.

This report contains maps (sheets 1-14) depicting water-level altitudes for 2012 for each of the three aquifers: maps depicting 1-year (2011-12) water-level changes for each aquifer; maps depicting 5-year (2007-12) water-level changes for each aquifer; maps depicting long-term (19902012 and 1977-2012) water-level changes for the Chicot and Evangeline aquifers, respectively; and a map depicting longterm (2000-12) water-level change for the Jasper aquifer. The point and contour data shown on the maps are available for download with the online published version of this report for all three aquifers (Chicot, Evangeline, and Jasper), along with Federal Geographic Data Committee compliant metadata.

In addition to maps depicting water-level altitudes and changes in the Chicot, Evangeline, and Jasper aquifers, this report also contains a map showing the location of the 11 borehole-extensometer sites in Harris and Galveston Counties (sheet 15). At these sites, borehole extensometers continuously record measured compaction of subsurface sediments of the Chicot and Evangeline aquifers. Graphs of these data from 12 of the 13 extensometers from 1973 (or later) through 2011 are shown on sheet 16 . Tables listing the data that were used to construct each of water-level map for each aquifer and the graphs of cumulative compaction also are included, as well as a brief description of the methods used for map construction.

\section{Hydrogeology of the Study Area}

The three primary aquifers in the Gulf Coast aquifer system are the Chicot, Evangeline, and Jasper (figs. 2-4), which are composed of laterally discontinuous deposits of gravel, sand, silt, and clay. The youngest and uppermost Chicot aquifer consists of Holocene- and Pleistocene-age sediments; the underlying Evangeline aquifer consists of Pliocene- and Miocene-age sediments; and the oldest and most deeply buried Jasper aquifer consists of Miocene-age sediments (fig. 2) (Baker, 1979, 1986). Through time, geologic and hydrologic processes created accretionary-sediment wedges (stacked sequences of sediments) more than 7,600 $\mathrm{ft}$ thick at the coast (fig. 2) (Chowdhury and Turco, 2006). The sediments composing the Gulf Coast aquifer system were deposited by fluvial-deltaic processes and subsequently were eroded and redeposited (reworked) by large episodic changes in sea level that occurred as a result of oscillations between glacial and interglacial climate conditions (Lambeck and others, 2002). The Gulf Coast aquifer system comprises hydrogeologic units that dip and thicken from northwest to southeast (fig. 2); the aquifers thus crop out in bands inland from and approximately parallel to the coast and become progressively more deeply buried and confined toward the coast. The Burkeville confining unit separates the Evangeline and Jasper aquifers and restricts groundwater flow between the two aquifers. There is no confining unit between the Chicot and Evangeline aquifers; therefore, the aquifers are hydraulically connected, which allows groundwater flow between the aquifers (fig. 2). Because of this hydraulic connection, water-level changes that occur in one aquifer can affect water levels in the adjoining aquifer (Kasmarek and Robinson, 2004). Evidence of this water-level interaction is substantiated by the two long-term water-level-change maps (1977-2012, sheets 5 and 10) showing that the areas where water-levels have declined or risen are approximately coincident for the Chicot and the Evangeline aquifers. The Chicot aquifer can be differentiated from the geologically similar Evangeline aquifer on the basis of hydraulic conductivity (Carr and others, 1985, p. 10) and where each aquifer outcrops - the Chicot aquifer outcrops closer to the coast compared to the Evangeline aquifer. The Jasper aquifer outcrops inland from the Evangeline aquifer. The Jasper can be differentiated from the Evangeline aquifer on the basis of water levels, which are shallower (closer to land surface) in the Jasper aquifer compared to those in the Evangeline aquifer. In the downdip parts of the aquifer system, the Jasper aquifer can be differentiated from the Evangeline aquifer on the basis 


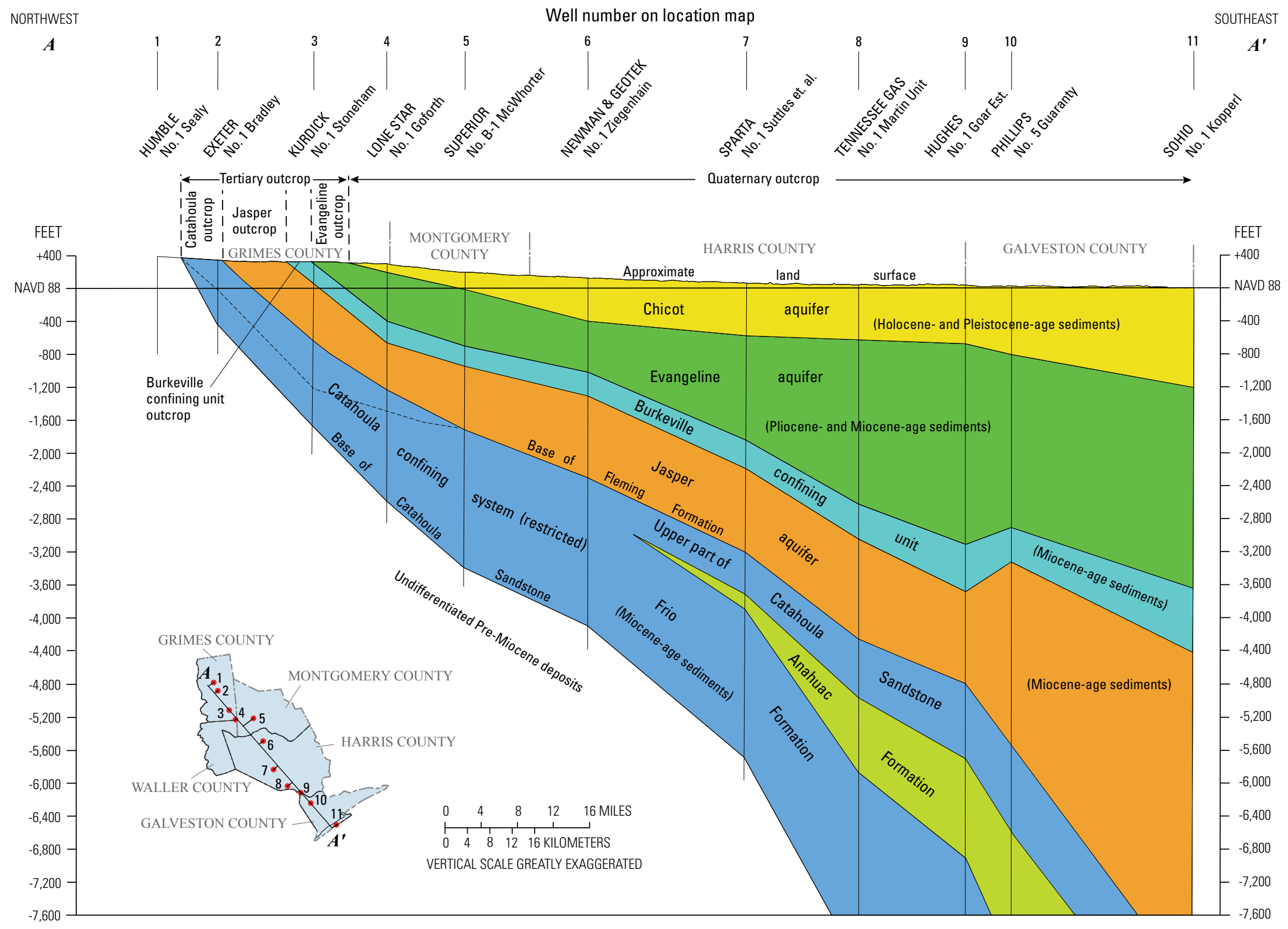

NAVD 88, North American Vertical Datum of 1988 


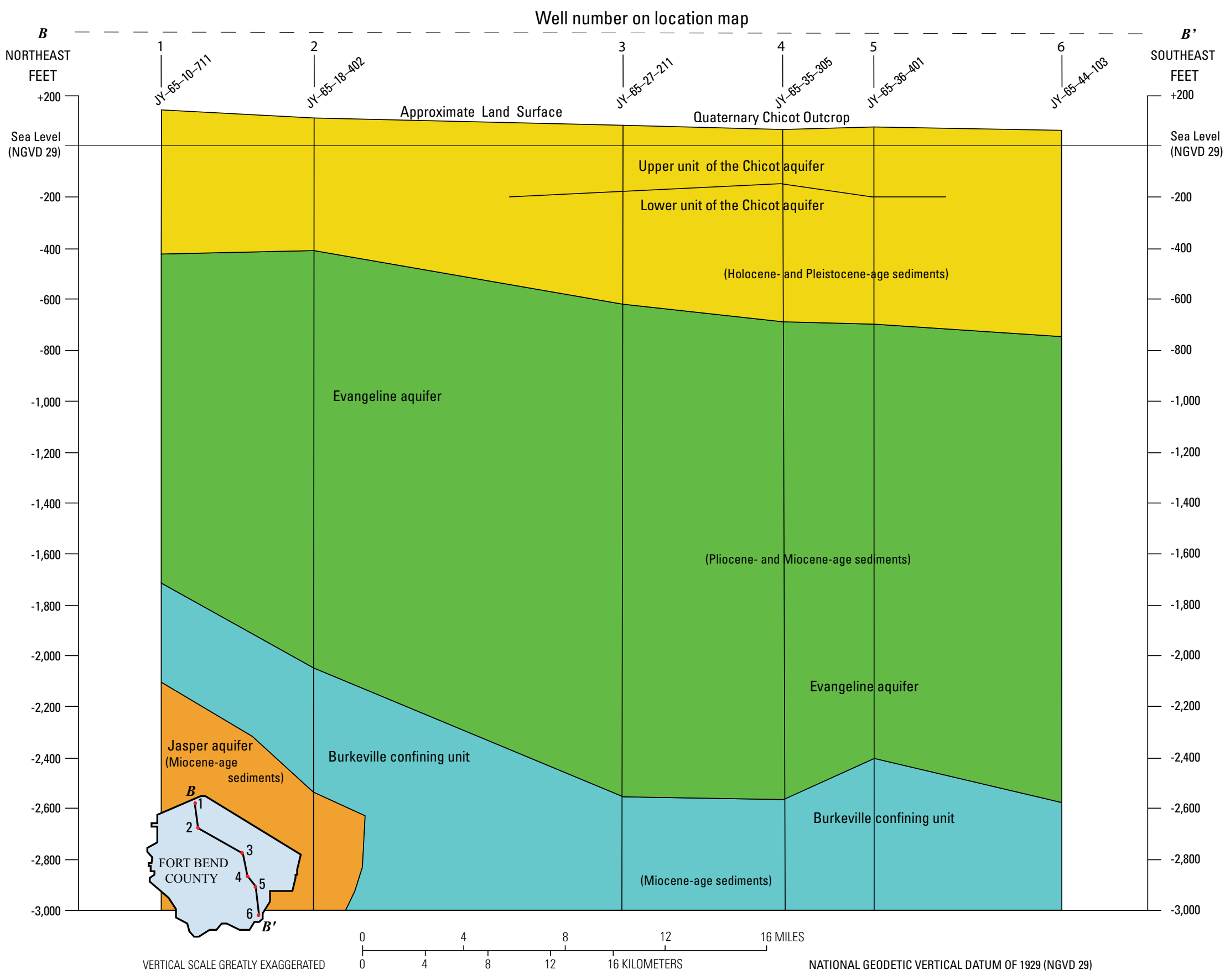

Figure 3. Hydrogeologic section of the Gulf Coast aquifer system in Fort Bend County, Texas (modified from Wesselman, 1972, fig. 30). 


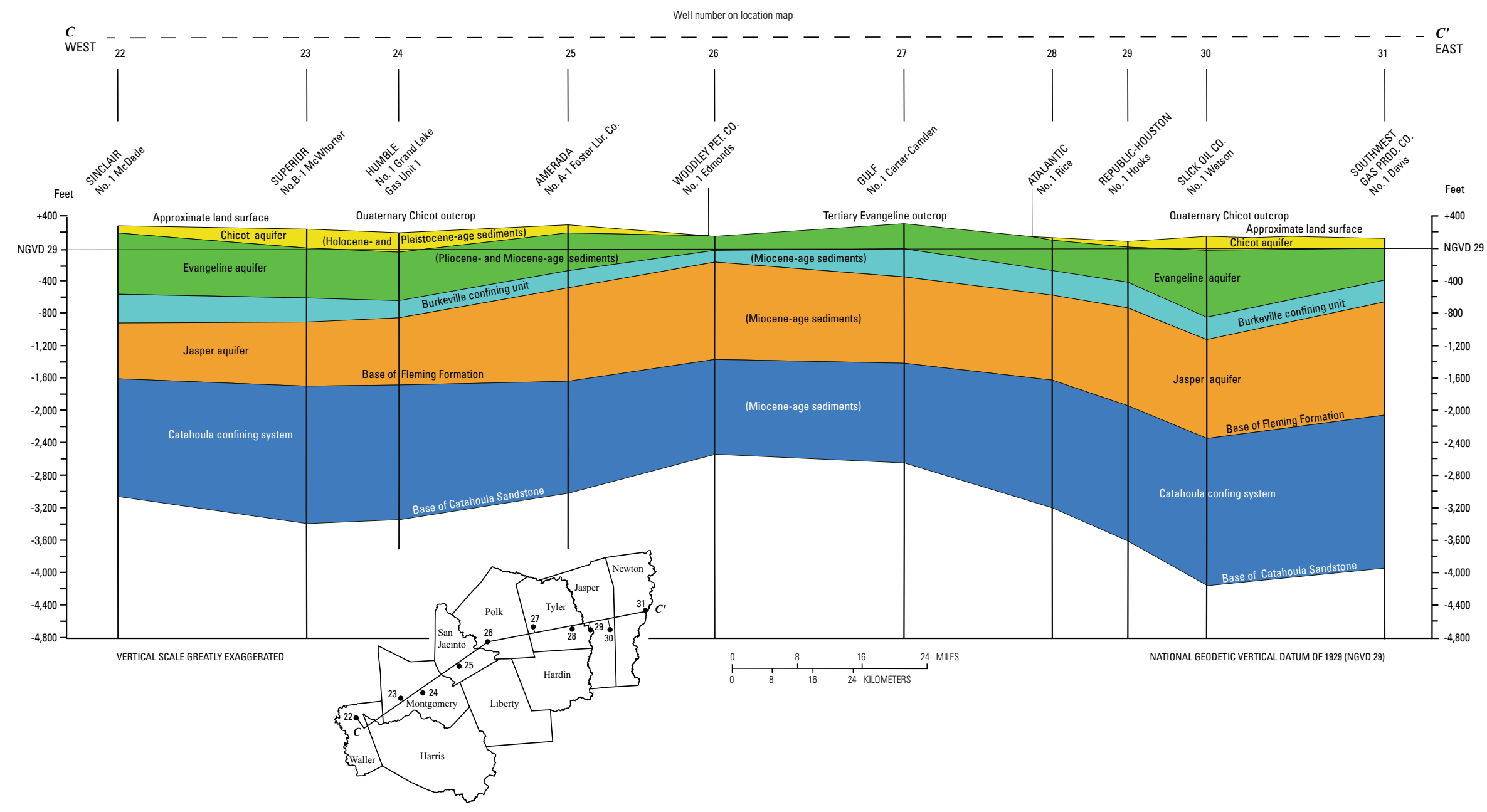

Figure 4. Hydrogeologic section of the Gulf Coast aquifer system in Waller, Harris, Montgomery, San Jacinto, Polk, Tyler, Jasper, and Newton Counties, Texas (modified from Baker, 1986, fig. 7). 
of stratigraphic position in relation to the Burkeville confining unit (figs. 2-4).

The hydrogeologic cross section $A-A^{\prime}$ (fig. 2) extends through the Houston-Galveston region from northwestern Grimes County, continues southeastward through Montgomery and Harris Counties, terminates at the coast in Galveston County, and shows the three aquifers thickening and dipping toward the coast. Comparing cross section $A-A^{\prime}$ (fig. 2) to cross section $B-B^{\prime}$ (fig. 3 ) in Fort Bend County shows that the thicknesses of the three aquifers similarly increase toward the coast. In central Harris, southern Montgomery, and Grimes Counties, the sediments of the updip Chicot and Evangeline aquifers become progressively thinner (fig. 2), and in northern Montgomery and Grimes County, the thickness of the sediments composing the Chicot aquifer are effectively insufficient for groundwater withdrawal (fig. 2). The hydrogeologic cross section of the Jasper aquifer (fig. 4) shows the thickness of the aquifer in the study area $(C-C)$. The perspective of figure 4 is approximately along strike (southwesterly to northeasterly) of the Jasper aquifer instead of along dip (northwest to southeast) for the Chicot and Evangeline aquifers (figs. 2 and 3).

Water in the Chicot, Evangeline, and Jasper aquifers is fresh (less than 1,000 milligrams per liter [mg/L] dissolvedsolids concentration) in the Houston-Galveston region, but it becomes more saline in the downdip and more deeply buried parts of the aquifers near the coast (Baker, 1979). In the groundwater-flow system, water discharges to streams or recharges the aquifers in the unconfined outcrop areas moving downward and coastward (Kasmarek and Robinson, 2004). Water that does not discharge to streams flows to intermediate and deep zones of the system southeastward of the outcrop areas, and there the water is withdrawn and discharged by wells or is naturally discharged by diffuse upward leakage in topographically low areas near the coast (Kasmarek and Robinson, 2004).Water in the coastal deep zones of the aquifers is more dense with dissolved-solids concentrations greater than $1,000 \mathrm{mg} / \mathrm{L}$. This higher density water causes the lower density freshwater that has not been captured and withdrawn by wells to be redirected as diffuse-upward leakage to shallow zones of the confined downdip areas of the aquifer system and to be ultimately discharged to coastal brackish water bodies (Kasmarek and Robinson, 2004).

\section{Subsidence and Compaction Processes}

Subsidence can occur as a result of potentiometricsurface declines in unconsolidated confined aquifers (Galloway and others, 1999). By 1979, as much as $10 \mathrm{ft}$ of land-surface subsidence had occurred in the HoustonGalveston region, and approximately $3,200 \mathrm{mi}^{2}$ of the 11,000-mi ${ }^{2}$ geographic area had subsided more than $1 \mathrm{ft}$ (Coplin and Galloway, 1999). Potentiometric-surface declines cause a decrease in hydraulic pressure (depressuring) that creates a load on the skeletal matrix of the sediments in the aquifer and adjacent confining units (fig. 5). Because sand layers are more transmissive and less compressible than are clay layers, sand layers depressure more rapidly compared to clay layers. In addition, when groundwater withdrawals are decreased, pressure equilibrium is reestablished more rapidly in the sand layers compared to the clay layers, and the amount of compaction of the sand layers is usually minor compared to the amount of compaction of the clay layers (Trahan, 1982; Galloway and others, 1999). The clay layers are often interbedded within the sand layers, and when depressuring occurs, the clay layers dewater more slowly compared to the sand layers. The compressibility of the clay layers is dependent on the thickness and hydraulic characteristics of the clay layers and the vertical stress of the sediment overburden. Slow drainage of the clay layers continues to occur until the excess residual pore pressure in the clay layers equilibrates with the pore pressure of the adjacent sand layers. As dewatering progresses, compaction of the clay layers continues until pressure equilibrium is attained. A similar loading process can occur in sand layers; however, a major difference is that the orientation of the individual clay grains realign as depressuring and dewatering progresses, becoming perpendicular to the applied vertical overburden load (Galloway and others, 1999). Essentially, the water stored in the clay layers prior to depressuring provides interstitial pore-space support to the clay-skeleton matrix. As water-levels decline, the clay layers dewater and depressure allowing the individual clay grains comprising the clay layer to reorient and compact. Additionally, compaction of the clay layers reduces the porosity and groundwater-storage capacity of the clay layers (fig. 5). Because most compaction of the clay layers is inelastic, about 90 percent of the compaction is permanent (Gabrysch and Bonnet, 1975). In areas where groundwater withdrawals have decreased, the water level in the aquifers rises and repressures the compacted clay layers, but only a small amount of rebound of the land-surface altitude occurs (Gabrysch and Bonnet, 1975). Although the compaction of one thin clay layer generally will not cause a noticeable decrease in the land-surface altitude, when numerous stacked clay- and sand-layer sequences (characteristic of the Gulf Coast aquifer system) depressure and compact, subsidence often occurs (Gabrysch and Bonnet, 1975).

\section{Data Collection and Analysis Methods}

Water-level data were obtained from wells by measuring the depth to water below land surface at each well. Measurements were obtained by using calibrated steel tape, air line, and electric water-level tape and also were obtained from reports of well operators. Antecedent pumping conditions and pumping status of nearby wells were not always known, although most wells were pumped at least once daily and some more frequently. At least two water-level measurements were made at each well while the well was not being pumped. To ensure that the water-level measurement recorded for each well was accurate, additional water-level measurements were 


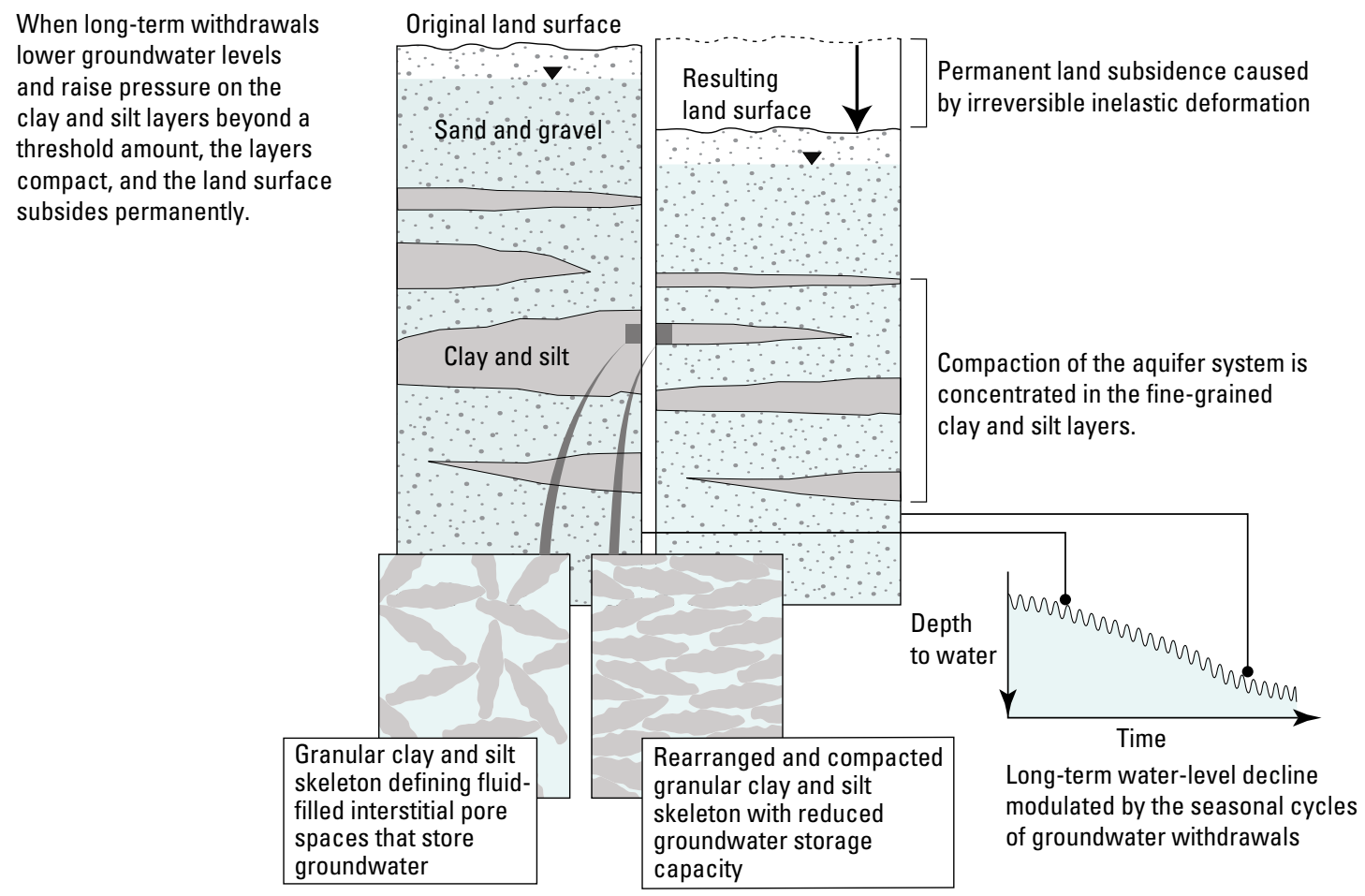

Figure 5. Diagram depicting the mechanism of subsidence in an aquifer composed of sand, gravel, clay, and silt (modified from Galloway and others, 1999, p. 9).

made as required. Water-level measurements in wells used to create sheets $1-14$ of this report were collected during December 2011-February 2012 to represent 2012 water-level altitudes (tables 1-3); during the winter months of December through February, water levels in the Houston-Galveston region are usually higher compared to the rest of the year because rates of groundwater withdrawals generally are at a minimum. Subsequently, these data were incorporated into a geographic information system (GIS) as point-data layers and used for the construction of sheets 1-14.

\section{Determination of Water-Level Altitudes}

The water-level-altitude data used to construct the waterlevel-altitude maps for the Chicot, Evangeline, and Jasper aquifers (sheets 1, 6, and 11, respectively) were calculated by subtracting the water-level measurement from the landsurface-altitude value for each well (point). Land-surface altitudes were referenced to the North American Vertical Datum of 1988 (NAVD 88; hereinafter, datum) (National Oceanic and Atmospheric Administration, 2008). Therefore, each point used for contour configuration on the three waterlevel-altitude maps is referenced to NAVD 88 (tables 1-3). For the Houston-Galveston region, water-level-altitude contours represent 2012 regional-scale depictions of the water levels in the Chicot, Evangeline, and Jasper aquifers. The areal extents and locations of these contours represent the combined effects of groundwater withdrawals from all groundwater wells in the study area. Similarly, water-level-change contours represent regional-scale depictions of water-level change during selected periods for each aquifer. Delineated areas showing contours of water-level rise or decline represent water-level changes in the aquifers caused by spatial and temporal changes in groundwater withdrawals. Water-level altitudes were depicted with contour intervals of 50 and $100 \mathrm{ft}$.

\section{Depicting Changes in Water-Level Altitudes}

Maps depicting changes in water-level altitudes in the Chicot, Evangeline, and Jasper aquifers were constructed for 1-year (2011-12), 5-year (2007-12), and various long-term (1990-2012 (Chicot and Evangeline), 1977-2012 (Chicot and Evangeline), and 2000-12 (Jasper)) periods. To create the various water-level-change maps, datasets of water-levelchange values (difference between the current year [2012] and historical water-level-altitude values) were used. The historical years (1977, 1990, and 2000) when the water-level-altitude maps were created and published as part of the USGS annual 
map series are coincident with the creation of the HGSD, FBSD, and LSGCD, respectively.

For the 1-year (2011-12) water-level-change maps (sheets 2, 7, and 12), water-level changes were computed as the difference between water-level altitude at each point (well) for which a water-level measurement was made in 2011 and in 2012. For the 5-year (2007-12) water-level-change maps (sheets 3, 8, and 13), water-level changes were computed the same as for the 1-year maps - the difference between water-level altitude at each well for which a water-level measurement was made in 2012 and 2007. Changes on the 5 -year maps are indicated by contours of equal water-level change. Each 5-year map was constructed by contouring the set of mapped point differences.

For the historical (1977-2012, 1990-2012, 2000-12) water-level-change maps (sheets $4,5,9,10$, and 14), waterlevel changes were computed as the difference between water-level altitude at each well for which a water-level measurement was made in 2012 and in the historical year (1977, 1990, and 2000). For wells measured in 2012 that had no corresponding measurement in the historical year, a GIS raster (gridded surface) (Worboys, 1995) was created from published historical water-level-altitude contours (1977, 1990, and 2000). The maps were constructed by contouring the set of mapped point values computed either as the difference in water-level altitude at each point (well) for which a water-level measurement was made in 2012 and in the historical year or as the difference in water-level altitude at that point in 2012 and the water-level altitude on a gridded surface of the historical year water-level-altitude map (Gabrysch, 1979; Kasmarek, 1997; Kasmarek and Houston, 2007). Gridded-surface values for the historical year (rather than actual measured values) were used to compute differences (mapped point values) because many of the wells measured in the historical year have been destroyed or were not measured in 2012. For the subset of wells measured in both 2012 and the historical year, the mapped point values used were the differences in water-levelaltitude values between 2012 and the historical year rather than the differences between 2012 water-level-altitude values and historical year gridded-surface values.

\section{Borehole Extensometers}

To install a borehole extensometer, a borehole is first drilled to a predetermined depth, generally below the depth of expected water-level decline. A steel outer casing with slip joints, which prevents crumpling and collapse of the well casing as clay compaction occurs, is then installed in the borehole. A smaller diameter pipe (often referred to as the "extensometer pipe") is inserted inside the outer casing, with the inner pipe terminating within the cement plug and extending above land surface and remaining rigid and fixed as clay compaction occurs (fig. 6). At land surface, a concrete slab is poured and connected to an array of vertical concrete piers extending down into the water table. This construction design helps to eliminate the continuous shrinking and swelling of the clayey surficial sediments associated with soil-moisture changes. The concrete piers connect the slab to the underlying unconsolidated sediments penetrated by the borehole. A metal gage house (not shown) is constructed on the slab, and a shaft-encoder and analog recorder are mounted to a steel table that is attached to the borehole-extensometer slab. A calibrated steel tape connects the recorder to the top of the inner pipe; because the steel table is anchored to the slab, changes in land-surface altitude can be accurately measured and recorded. These recorded values represent the cumulative compaction at the site. The scientific theory and operation of a borehole extensometer is further explained by Gabrysch (1984).

Extensometer data are used to quantify the rate of compaction in aquifer formations, thereby providing water-resource managers a tool for evaluating the effects on subsidence rates caused by changes in the amount of groundwater withdrawn from the Chicot and Evangeline aquifers. For this report, borehole extensometer data of the compaction of subsurface sediments in the Chicot and Evangeline aquifers were evaluated at 13 borehole extensometers at 11 sites in Harris and Galveston Counties. To quantify the rate of compaction in aquifer formations, a network of extensometers was installed beginning in 1973 at selected sites throughout Harris and Galveston Counties. Five extensometers were installed in Harris or Galveston County in July 1973: KH-64-33-920 (Texas City-Moses Lake) in Galveston County and LJ-65-22-622 (East End), LJ-6516-930 (Baytown C-1), LJ-65-16-931 (Baytown C-2), and LJ-65-32-625 (Seabrook) in Harris County. A previous borehole extensometer installed in 1962 in Harris County (LJ-65-32-401 [Johnson Space Center]) was included in the network. Since July 1973, routine measurements of claycompaction data from the Johnson Space Center extensometer have been collected and are included in this report. Additional extensometers were added to the network during 1974-76 in Harris County: LJ-65-12-726 (Addicks) in 1974, LJ-6523-322 (Pasadena) in 1975, and LJ-65-32-428 and LJ-6532-424 (Clear Lake) in 1976. The last three extensometers in the current (2012) network were installed in Harris County in 1980: LJ-65-07-909 (Lake Houston), LJ-6514-746 (Northeast), and LJ-65-21-226 (Southwest). Since activation or installation between 1973 and 1980, compaction measurements have been obtained at these 13 extensometers sites at least monthly, thereby providing site-specific rates of compaction accurate within $0.001 \mathrm{ft}$. Measured compaction from 12 of the 13 borehole-extensometer sites are shown in table 4. Cumulative compaction data for the shallow extensometer (LJ-65-32-424) is not listed in table 4 because the data from the nearby extensometer ( $\mathrm{LJ}-65-32-428$ ) is closely similar. 


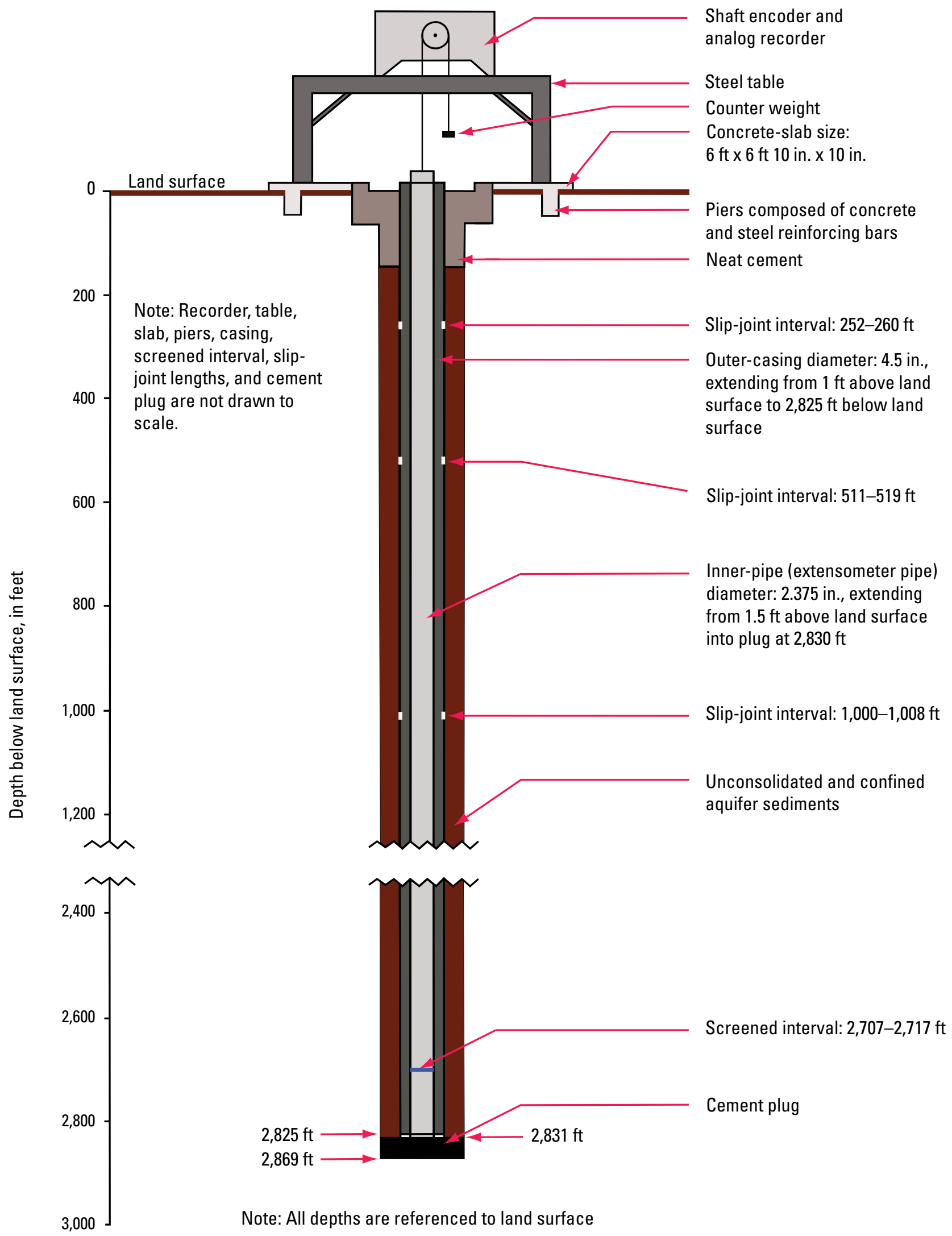

Figure 6. Diagram depicting cross-sectional perspective of the borehole extensometer/piezometer (LJ-65-23-322) located at Pasadena, Texas (ft, foot; in., inch). 
Each borehole extensometer has a 10 -ft screened interval above the cement plug that allows water to flow into the center pipe and thus functions as a piezometer (small-diameter well used to measure water level in the aquifer). A water-level measurement is made during each extensometer site visit. If the depth of the screened interval is located entirely within the Chicot or Evangeline aquifer, these water-level measurements are considered during construction of the annual water-levelaltitude maps for those aquifers.

\section{Quality Assurance}

Protocols for the collection and review of water-levelaltitude data were followed as described in the USGS Texas Water Science Center internal document "Quality Assurance Plan for Groundwater Activities" (app. 7.3, "Groundwater Data Management Plan" [Greg P. Stanton, U.S. Geological Survey, written commun., 2010]). All data were archived in the USGS National Water Information System (NWIS) (U.S. Geological Survey, 2012).

The annual (2012) regional-scale depictions of waterlevel altitudes presented in this report were derived from water-level-measurement data collected during December 2011-February 2012 throughout an 11-county area that includes the greater Houston-Galveston area. The water-level altitudes of the Chicot, Evangeline, and Jasper aquifers are continually changing in response to changes in hydrologic conditions and the rates of groundwater withdrawals and precipitation. Therefore, the water level in any of the three aquifers may have declined or risen since the most recent water-level measurements were made. Antecedent withdrawal rates and pumping status of nearby wells were not always known and could have affected the representativeness of the water-level data that were collected.

\section{Water-Level Altitudes and Changes}

Locations of wells used to construct the water-levelaltitude and water-level-change maps for the Chicot, Evangeline, and Jasper aquifers are shown in appendix 1. The well index numbers on the three maps (apps. 1.1, 1.2, and 1.3) coincide with tabular data (tables 1-3, respectively) for each water-level-altitude or water-level-change map.

The Chicot and Evangeline aquifer maps depict approximate water-level altitudes in 2012 and water-level changes for 2011-12, 2007-12, 1990-2012, and 1977-2012 (sheets 1-5 and 6-10, respectively). Depictions of longterm water-level change (1977-2012; sheets 5 and 10) show areas of water-level decline in northern, northwestern, and southwestern Harris County and a broad area of water-level rise in southeastern Harris and northern Galveston Counties.

The Jasper aquifer maps show approximate waterlevel altitudes in 2012 and water-level changes for 2011-12,
2007-12, and 2000-12 (sheets 11-14). Depictions of longterm water-level change (2000-12; sheet 14) indicate that water-level declines have occurred in most of Montgomery County and north-central Harris County.

Except for the 2011-12 change maps, the water-levelaltitude contours were constructed by using contour intervals relative to the specific range of water-level-altitude changes for a given map. Adjusting the contour intervals in this way helped to present a clear depiction of regional-scale waterlevel-altitude changes.

\section{Chicot Aquifer}

Water-level measurements from 174 wells (table 1) were used to construct the 2012 water-level-altitude map of the Chicot aquifer. In 2012, water-level-altitude contours ranged from $250 \mathrm{ft}$ below datum in a small area in southwestern Harris County to $200 \mathrm{ft}$ above datum in western-central Montgomery County (sheet 1). Depictions of water-levelchange for 2011-12, 2007-12, 1990-2012, and 1977-2012 are shown on sheets $2,3,4$, and 5, respectively. The numbers of water-level-measurement pairs used to construct the change maps were 169 for 2011-12, 159 for 2007-12, 148 for 1990-2012, and 134 for 1977-2012 (table 1).

Changes in water-level altitudes in the Chicot aquifer, during 2011-12, ranged from a 48-ft decline in east-central Brazoria County to an $18-\mathrm{ft}$ rise in southeastern Harris County (sheet 2). During 2007-12, contoured changes in water-level altitudes ranged from a 60 - $\mathrm{ft}$ decline in northwestern Harris County to a 40-ft rise in west-central Harris County (sheet 3). For 1990-2012, changes in water-level altitude ranged from a $100-\mathrm{ft}$ decline in south-central Montgomery County to an 80-ft rise in southeastern Harris County (sheet 4). For 1977-2012, contoured changes in water-level altitude ranged from a 100 $\mathrm{ft}$ decline in southwestern Harris County to a 200 - $\mathrm{ft}$ rise in southeastern Harris County (sheet 5). The long-term waterlevel change (1977-2012) depictions indicate areas of decline in northern, northwestern, and southwestern Harris County and across central and eastern Fort Bend County, with a broad area of water-level rise in central, eastern, and southeastern Harris and northern Galveston Counties (sheet 5).

\section{Evangeline Aquifer}

Water-level measurements from 356 wells (table 2) were used to construct the 2012 water-level-altitude map of the Evangeline aquifer. In 2012, water-level-altitude contours ranged from 300 below datum in isolated areas located in south-central Montgomery County and north-central Harris County, southwest Harris County, and northeastern Fort Bend County to $200 \mathrm{ft}$ above datum near the county boundary intersection of Waller, Montgomery, and Grimes Counties (sheet 6). Depictions of water-level-change for 2011-12, 
2007-12, 1990-2012, and 1977-2012 are shown on sheets $7,8,9$, and 10 , respectively. The numbers of water-levelmeasurement pairs used to construct the change maps were 321 for 2011-12, 293 for 2007-12, 286 for 1990-2012, and 272 for 1977-2012 (table 2).

The 2011-12 water-level-altitude changes in the Evangeline aquifer ranged from a 90 -ft water-level decline to a 39-ft rise in southwestern Harris County (sheet 7). For 2007-12, contoured changes in water-level altitude ranged from an 80-ft decline in north-central Fort Bend County and in south-central Montgomery County to an $80-\mathrm{ft}$ rise in southwest-central Harris County (sheet 8). For 1990-2012, contoured changes in water-level altitude ranged from a 220-ft decline in south-central Montgomery County to a 220-ft rise in southeastern Harris County (sheet 9). For 1977-2012, contoured change ranged from a 360-ft decline in south-central Montgomery County to a $260-\mathrm{ft}$ rise in southeastern Harris County (sheet 10). The long-term waterlevel change (1977-2012) depictions indicate areas of decline extending from northwest Brazoria County, across all of Fort Bend County, about all of western and north-central Harris County, into southwestern-central Liberty County, into south Montgomery County, and eastern Waller County. A broad area of water-level rise exists in central, eastern, and southeastern Harris County (sheet 10). This broad area of water level rise in Harris County also extends into the northern and northwestern part of Brazoria County.

\section{Jasper Aquifer}

Water-level measurements from 106 wells (table 3) were used to construct the 2012 water-level-altitude map of the Jasper aquifer. For 2012, water-level-altitude contours ranged from $250 \mathrm{ft}$ below datum in south-central Montgomery County to $250 \mathrm{ft}$ above datum in northwestern Montgomery County (sheet 11).

Depictions of water-level change for 2011-12, 2007-12, and 2000-12 are shown on sheets 12,13 , and 14, respectively. The numbers of water-level-measurement pairs used to construct the change maps were 99 for 2011-12, 70 for 2007-12, and 90 for 2000-12 (table 3).

For the period 2011-12 in the Jasper aquifer, water-levelaltitude changes ranged from a 74-ft decline in north-central Montgomery County to a 4 - $\mathrm{ft}$ rise in western Grimes County (sheet 12). For 2007-12, contoured changes in waterlevel altitude ranged from a 120 -ft decline in south-central Montgomery County and north-central Harris County, as well as in north-central Montgomery County, to no change in northwestern Montgomery County and southwestern Walker County (sheet 13). For 2000-12, water-level declines occurred over most of Montgomery County, north-central Harris County, eastern Grimes County, and Waller County; contoured changes in water-level altitude ranged from a $220-\mathrm{ft}$ decline in south-central Montgomery County to no change in far northwestern Montgomery County (sheet 14).

\section{Compaction in the Chicot and Evangeline Aquifers}

Compaction of subsurface sediments (mostly of the clay layers because little compaction occurs in sand layers; refer to "Subsidence and Compaction Processes" section) composing the Chicot and Evangeline aquifers was recorded continuously at the 13 borehole extensometers at 11 sites (sheet 15) by using analog chart recorders. The rate of subsurface sediment compaction varied from site to site (sheet 16). Graphs of compaction are shown for 1973 (or later) through 2011 (depending on when each extensometer was installed) for 12 of the 13 extensometers (sheet 16); compaction data used for the graphs are listed in tables $4 A-L$. Compaction measured by the shallower of the two extensometers (LJ-65-32-424) located at the Clear Lake site is not shown on sheet 16 because the recorded data are very similar to that measured by the deeper extensometer (LJ-65-32-428) at the site. The selected depth of the extensometer determines the total thickness of sediment over which clay compaction is measured by the extensometer. Five extensometers measure compaction in the sediments of the Chicot aquifer (East End [LJ-65-22-622], Johnson Space Center [LJ-65-32-401], Texas City-Moses Lake [KH-64-33-920], Baytown C-1 [LJ-65-16-930], and Seabrook [LJ-65-32-625]), and seven extensometers measure compaction in the sediments of the Chicot and Evangeline aquifers (Lake Houston [LJ-65-07-909], Northeast [LJ-6514-746], Southwest [LJ-65-21-226], Addicks [LJ-65-12726], Baytown C-2 [LJ-65-16-931], Clear Lake [LJ-65-32428], and Pasadena [LJ-65-23-322]) (sheet 16). From the early 1900 s until 2001, as much as $12-13 \mathrm{ft}$ of subsidence has occurred in the Pasadena and Baytown areas in Harris County (Kasmarek, Gabrysch, and Johnson, 2010). The graphs of cumulative compaction data from installation in 1975 through 2011 for the Pasadena extensometer and from installation in 1973 through 2011 for the two Baytown extensometers indicate compaction values of $0.505,0.980$, and $1.123 \mathrm{ft}$, respectively (sheet 16; tables $4 L, 4 H$, and $4 I$, respectively). Most of the land-surface subsidence (77-97 percent) in the Houston-Galveston region occurred prior to 1973, when the installation of extensometers initially began (Kasmarek, Johnson, and Ramage, 2010).

Prior to the creation of HGSD in 1975, the withdrawal of groundwater from the Chicot and Evangeline aquifers was unregulated, and water levels in the aquifers were declining with associated depressuring, dewatering, and compaction of clay layers (Coplin and Galloway, 1999). By 1977, the withdrawals had resulted in water-level-altitude declines of 300 and $350 \mathrm{ft}$ below datum in the Chicot and Evangeline aquifers, respectively, in southeastern Harris County (Gabrysch, 1979), and correspondingly, by 1979, as much as $10 \mathrm{ft}$ of subsidence had occurred in the Houston-Galveston region (Coplin and Galloway, 1999). The rate of compaction is different at each site because of the groundwater withdrawal 
rates in the areas of each extensometer site and the varying clay-to-sand ratios of the subsurface sediments. When reductions in groundwater withdrawals were first mandated following the creation of the HGSD in 1975, the rate of groundwater withdrawal began to decrease as well as the rate of clay compaction (sheet 16). Coincident with the curtailment of groundwater withdrawals, water levels of the aquifers began to recover and rise. The decrease of groundwater withdrawal allowed the water levels in the Chicot and Evangeline aquifers to rise (recover) as much as $200 \mathrm{ft}$ and $260 \mathrm{ft}$, respectively (1977-2012 long-term water-level-altitude-change maps [sheets 5 and 10]), in the areas encompassing the extensometer sites.

For the period of record 1973-2011, the measured compaction of subsurface sediments in the Chicot and Evangeline aquifers ranged from $0.102 \mathrm{ft}$ at the Texas CityMoses Lake borehole extensometer (table $4 G$ ) to $3.621 \mathrm{ft}$ at the Addicks extensometer (table $4 E$ ). The graphs of cumulative-compaction data indicate that the compaction rates were substantially higher in the early years after the extensometers were initially installed compared to compaction rates in subsequent years. Evaluation of the cumulative compaction graphs on figure 16 indicates that the asymptotic compaction-rate decreases were directly related to the curtailment of groundwater withdrawals in areas adjacent to the extensometer sites caused by regulatory mandates of the HGSD. As the water levels of the aquifers began to rise or rebound, the hydrostatic pressure increased, and excess residual pore pressure equilibrated; hence, the rates of compaction progressively decreased. Coinciding with compaction-rate decreases, the long-term water-level changes for 1990-2012 and 1977-2012 in the Chicot and Evangeline aquifers (sheets 4 and 5 and sheets 9 and 10, respectively) indicate that, except for the Addicks extensometer, the locations of these extensometers coincide with these relatively large areas of water-level rise. Clay-compaction data from the Addicks extensometer (table $4 E$ ) indicates that the rate of compaction continued steadily through mid-2003. The reason the rate remained steady during this period is that the extensometer is located in Regulatory Area 3 of the HGSD and, as such, was not scheduled for a 30-percent groundwater reduction until 2010 (Harris-Galveston Subsidence District, 2010). Therefore, from mid-1974 through mid-2003, groundwater withdrawal was not as strongly curtailed in the area adjacent to the Addicks extensometer site compared to withdrawal rates in Regulatory Areas 1 and 2 (fig. 1); hence clay compaction continued at the historical rate for the site of about $0.1 \mathrm{ft}$ per year. Additionally, the rate of compaction at the Addicks extensometer during August 2003-December 2003 decreased to about $0.004 \mathrm{ft}$ because an adjacent publicsupply well field was inoperative during this period. From December 2003 until March 2006, recorded data at the Addicks extensometer indicates an increase (rebound) in land-surface altitude of about $0.092 \mathrm{ft}$. The graph of clay compaction from the Seabrook extensometer indicates a seasonal sinusoidal trend showing that the land-surface altitude decreases in the hot and dry summer months as the surficial montmorillinitic clayey sediments desiccate and shrink. Conversely, as the heat of the summer dissipates and the cooler and wetter winter months arrive, the sediments rehydrate, thereby causing the altitude of the land surface to increase or heave (swell).

Compaction data for the Texas City-Moses Lake borehole extensometer site indicate that not only has the rate of compaction been halted but also, since about 1981, a slight land-surface rise of approximately $0.091 \mathrm{ft}$ has occurred. The graphs of compaction data for the Pasadena, Clear Lake, Seabrook, Baytown C-1 and C-2, and Johnson Space Center extensometers indicate a slight increase in land-surface altitude from late 1978 to early 1980 because a ruptured natural gas well pressurized the confined aquifer system and caused water levels to rise in the area adjacent to the well (Gabrysch, 1984). Over a period of about 2 years, the pressure in the aquifer slowly dissipated, and the rates of compaction subsequently returned to similar rates that existed before the pressuring event. The graphs of compaction data for the two Baytown extensometers indicate a noticeable amount of seasonal variation from late 1973 to late 1982, and was determined to be caused by the expansive (shrink and swell) characteristics of the montmorillonitic clay within the aquifer sediments. To address the problem of shrinking and swelling of clays at the borehole extensometer sites, in 1982, a modification was made to the original design of the borehole extensometers by installing a system of vertical piers that are anchored to the concrete slabs of the extensometers and extend downward to the depth of the water table (fig. 6). By comparing the clay compaction graphs before and after 1982, it can be seen that these design modifications improved the accuracy of the data.

\section{Data Limitations}

Most land-surface altitudes for wells in this report are estimates from USGS 7.5-minute topographic quadrangle maps. Land-surface altitudes for 2009 and later for the wells in Harris County are derived from the digital elevation model of the 2001 Tropical Storm Allison Recovery Project that used Light Detection and Ranging (LiDAR) technology (Harris County Flood Control District, Tropical Storm Allison Recovery Project, 2002). These altitudes are referenced to NAVD 88 by using Corpscon version 6 (U.S. Army Corps of Engineers, 2006). LiDAR data were contoured at a 1 -ft interval, providing 0.5 -ft accuracy. The 7.5 -minute topographic maps for the Gulf Coast area were normally contoured at a 5 -ft interval, thereby providing 2.5 -ft accuracy; thus, the LiDAR data provided about five times better accuracy when compared to topographic maps (Kasmarek, Gabrysch, and Johnson, 2010). In addition, the 7.5-minute topographic maps have not been updated with changes in landsurface altitude that might have occurred since publication of the topographic map. The effects of land-surface-altitude 
changes on water-level-change maps need to be accounted for if the change maps are to accurately reflect differences between current-year and previous-year water-level-altitude maps (each of which reflects the best available land-surface altitudes of wells).

The depictions of water-level altitudes and changes at any specific location are considered to represent a regionalscale approximation and, as such, are not intended for use in engineering or other design applications. The water-level measurements collected for this report were rounded to the nearest foot; the values shown on the maps represent a mathematical approximation that could vary as much as $\pm 0.5 \mathrm{ft}$, in addition to accuracies associated with the source data. Use of these data for critical or local-scale applications is not advised without full awareness of the data limitations. Users need to exercise discretion when drawing conclusions or making policy decisions on the basis of these contoured depictions.

Compaction data recorded at each borehole extensometer site (sheet 16) are the cumulative clay-compaction for subsurface sediments above the depth of the cement plug (fig. 6); any compaction or vertical movement that occurs below these depths is not measured by the extensometer. Depending on the total depth of the borehole extensometer, the compaction of subsurface sediments for a given extensometer could represent solely the sediments of the Chicot aquifer (for example, the Baytown $\mathrm{C}-1$ extensometer) or represent the sediments of both the Chicot and Evangeline aquifers (for example, the Addicks extensometer). In addition to differences in the rates of groundwater withdrawals in the areas of each extensometer site, the clay-to-sand ratio is different also at each site; hence, the rate of compaction varies from site to site (sheet 16). Therefore, it is not possible to extrapolate or infer a rate of clay compaction for an area on the basis of the rate of compaction measured at a nearby extensometer.

\section{Summary}

The Houston-Galveston region-comprising Harris, Galveston, Fort Bend, Montgomery, Brazoria, Chambers, Liberty, San Jacinto, Walker, Grimes, Waller, and Chambers Counties - represents one of the largest areas of subsidence in the United States. By 1979, as much as 10 feet (ft) of landsurface subsidence had occurred in the Houston-Galveston region, and approximately $3,200 \mathrm{mi}^{2}$ of the $11,000-\mathrm{mi}^{2}$ geographic area had subsided more than $1 \mathrm{ft}$. Groundwater withdrawn from the Chicot, Evangeline, and Jasper aquifers has been the primary source of water for municipal supply, industrial and commercial use, and irrigation in the HoustonGalveston region, Texas, since the early 1900s. Most of the subsidence in the Houston-Galveston region has occurred as a direct result of groundwater withdrawals that depressured and dewatered the Chicot and Evangeline aquifers, thereby causing compaction of the clay layers of the aquifer sediments.
To address the issues associated with land-surface subsidence and subsequent increased flooding, the 64th Texas State Legislature in 1975 authorized the establishment of the Harris-Galveston Subsidence District to regulate and reduce groundwater withdrawals in Harris and Galveston Counties. Subsequently, the Texas State Legislature established the Fort Bend Subsidence District in 1989 and the Lone Star Groundwater Conservation District in 2001 to regulate groundwater withdrawals in Fort Bend and Montgomery Counties, respectively. The Brazoria County Groundwater Conservation District was created in 2003 with the purpose to maintain the quality and availability of the county's groundwater resource for current users and future generations. This report-prepared by the U.S. Geological Survey in cooperation with the Harris-Galveston Subsidence District, City of Houston, Fort Bend Subsidence District, Lone Star Groundwater Conservation District, and the Brazoria County Groundwater Conservation District - is one in an annual series of reports depicting water-level altitudes and waterlevel changes in the Chicot, Evangeline, and Jasper aquifers and compaction in the Chicot and Evangeline aquifers in the Houston-Galveston region.

The report contains maps showing 2012 water-level altitudes for the Chicot, Evangeline, and Jasper aquifers; maps showing 1-year (2011-12) water-level-altitude changes for each aquifer; maps showing 5-year (2007-12) water-levelaltitude changes for each aquifer; maps showing long-term (1990-2012 and 1977-2012) water-level-altitude changes for the Chicot and Evangeline aquifers; a map showing long-term (2000-12) water-level-altitude change for the Jasper aquifer; a map showing locations of borehole extensometer sites; and graphs showing borehole-extensometer measured compaction of subsurface sediments 1973 (or later) through 2011. Tables listing the data that were used to construct each water-level map for each aquifer and the clay-compaction graphs are included.

Water levels in wells screened in the Chicot, Evangeline, and Jasper aquifers were measured during December 2011February 2012 and used to calculate the 2012 water-level altitudes (water levels usually are higher in winter compared to the rest of the year). Water-level measurements from 174 wells were used to construct the 2012 water-level-altitude map of the Chicot aquifer; contours ranged from $250 \mathrm{ft}$ below the North American Vertical Datum of 1988 (NAVD 88, hereinafter, datum) in a small area in southwestern Harris County to $200 \mathrm{ft}$ above datum in western-central Montgomery County. Water-level-altitude changes in the Chicot aquifer for 2011-12 ranged from a 48-ft decline to an 18-ft rise; contoured changes in water-level altitudes for 2007-12 ranged from a $60-\mathrm{ft}$ decline to a $40-\mathrm{ft}$ rise, for 1990-2012 ranged from a 100-ft decline to an 80-ft rise, and for 1977-2012 ranged from a $100-\mathrm{ft}$ decline to a $200-\mathrm{ft}$ rise.

Water-level measurements from 356 wells were used to construct the 2012 water-level-altitude contours of the Evangeline aquifer; contours of water-level altitudes in 2012 
ranged from $300 \mathrm{ft}$ below datum in isolated areas located in south-central Montgomery County and north-central Harris County, in southwest Harris County, and in northeastern Fort Bend County to $200 \mathrm{ft}$ above datum near the county boundary intersection of Waller, Montgomery, and Grimes Counties. Water-level-altitude changes in the Evangeline aquifer for 2011-12 ranged from a $90-\mathrm{ft}$ decline to a $39-\mathrm{ft}$ rise, for 2007-12 ranged from an $80-\mathrm{ft}$ decline to an $80-\mathrm{ft}$ rise, for 1990-2012 ranged from a $220-\mathrm{ft}$ decline to a $220-\mathrm{ft}$ rise, and for 1977-2012 ranged from a 360-ft decline to a $260-\mathrm{ft}$ rise.

Water-level measurements from 106 wells were used to construct the 2012 water-level-altitude contours of the Jasper aquifer. Contours ranged from $250 \mathrm{ft}$ below datum in south-central Montgomery County to $250 \mathrm{ft}$ above datum in northwestern Montgomery County. Water-level-altitude changes in the Jasper aquifer for 2011-12 ranged from a $74-\mathrm{ft}$ decline to a 4-ft rise, for 2007-12 ranged from a $120-\mathrm{ft}$ decline to no change, and for 2000-12 ranged from a $220-\mathrm{ft}$ decline to no change. For the Chicot and Evangeline aquifers, maps of long-term water-level change (1977-2012) depict areas of decline in northern, northwestern, and southwestern Harris County and a broad area of water-level rise in southeastern Harris and northern Galveston Counties. For the Jasper aquifer, depictions of long-term water-level change (2000-12) indicate that water-level declines have occurred in most of Montgomery County and in north-central Harris County.

Compaction of subsurface sediments (mostly in the clay layers) composing the Chicot and Evangeline aquifers was recorded continuously at the 13 borehole extensometers at 11 sites in Harris and Galveston Counties. The graphs of cumulative-compaction data indicate that the compaction rates were substantially higher in the early years when the extensometers were initially installed compared to compaction rates in subsequent years. When reductions in groundwater withdrawals were mandated following the creation of the Harris-Galveston Subsidence District in 1975, the rate of groundwater withdrawal began to decrease as well as the rate of clay compaction. Coincident with the curtailment of groundwater withdrawals, the water levels of the Chicot and Evangeline aquifers have risen as much as $200 \mathrm{ft}$ and $260 \mathrm{ft}$, respectively, as shown on the 1977-2012 long-term waterlevel-change maps. Cumulative-clay compaction (1973-2011) measured by the borehole-extensometer network in the Chicot and Evangeline aquifers ranged from $0.102 \mathrm{ft}$ at the Texas City-Moses Lake extensometer (KH-64-33-920) to 3.621 $\mathrm{ft}$ at the Addicks extensometer (LJ-65-12-726). The rate of compaction is different at each site because of the groundwater withdrawal rates in the areas of each extensometer site and the varying clay-to-sand ratios of the subsurface sediments. Therefore, it is not possible to extrapolate or infer a rate of clay compaction for an area on the basis of the rate of compaction measured at a nearby borehole extensometer.

\section{References Cited}

Allen, A.S., 1969, Geologic settings of subsidence, in Varnes, D.J., and Kiersch, George, eds., Reviews in engineering geology: Geological Society of America, v. 2, p. 305-342.

Baker, E.T., Jr., 1979, Stratigraphic and hydrogeologic framework of part of the Coastal Plain of Texas: Texas Department of Water Resources Report 236, 43 p.

Baker, E.T., Jr., 1986, Hydrology of the Jasper aquifer in the southeast Texas Coastal Plain: Texas Water Development Board Report 295, 64 p.

Barbie, D.L., Coplin, L.S., and Locke, G.L., 1991, Approximate altitude of water levels in wells in the Chicot and Evangeline aquifers in the Houston area, Texas, January-February 1990: U.S. Geological Survey Open-File Report 91-240, 2 sheets.

Brazoria County Groundwater Conservation District, 2008, Brazoria County Groundwater Conservation District groundwater management plan: 62 p., accessed June 7, 2012, at http://www.bcgroundwater.org/documents/ Brazoria_GW_Management\%20Plan_111308_Approved. pdf.

Carr, J.E., Meyer, W.R., Sandeen, W.M., and McLane, I.R., 1985, Digital models for simulation of ground-water hydrology of the Chicot and Evangeline aquifers along the Gulf Coast of Texas: Texas Department of Water Resources Report 289, $101 \mathrm{p}$.

Chowdhury, A.H., and Turco, M.J., 2006, Geology of the Gulf Coast aquifer, Texas, chap. 2 of Mace, R.E., Davidson, S.C., Angle, E.S., and Mullican, W.F., eds., Aquifers of the Gulf Coast of Texas: Texas Water Development Board Report 365, p. 23-50, accessed March 7, 2011, at http://www.twdb. state.tx.us/publications/reports/numbered_reports/doc/R365/ ch02-Geology.pdf.

Coplin, L.S., 2001, Water-level altitudes in wells completed in the Jasper aquifer, greater Houston area, Texas, spring 2000: U.S. Geological Survey Open-File Report 2001-147, 1 sheet.

Coplin, L.S., and Galloway, Devin, 1999, Houston-Galveston, Texas-Managing coastal subsidence, in Galloway, Devin, Jones, D.R., and Ingebritsen, S.E., eds., Land subsidence in the United States: U.S. Geological Survey Circular 1182, p. $35-48$.

Fort Bend Subsidence District, 2009, Fort Bend Subsidence District 2003 regulatory plan [amended 2007, 2009]: 14 p., accessed March 7, 2011, at http://www.fbsubsidence.org/ assets/pdf/FBRegPlan.pdf. 
Gabrysch, R.K., 1979, Approximate altitude of water levels in wells in the Chicot and Evangeline aquifers in the Houston area, Texas, spring 1977 and spring 1978: U.S. Geological Survey Open-File Report 79-334, 4 sheets.

Gabrysch, R.K., 1984, Ground-water withdrawals and landsurface subsidence in the Houston Galveston region, Texas, 1906-80: Texas Department of Water Resources Report 287, 64 p.

Gabrysch, R.K., and Bonnet, C.W., 1975, Land-surface subsidence in the Houston-Galveston region, Texas: Texas Water Development Board Report 188, 19 p.

Galloway, Devin, Jones, D.R., and Ingebritsen, S.E., eds., 1999, Land subsidence in the United States: U.S. Geological Survey Circular 1182, 177 p.

Harris County Flood Control District, Tropical Storm Allison Recovery Project, 2002, Harris County, Texas LiDAR, digital data: Charleston, S.C., National Oceanic Atmospheric Administration Coastal Services Center, accessed, May 20, 2011, at http://www.csc.noaa.gov/crs/ $\mathrm{tcm} /$ ldartdat/metatemplate/tx2001_harris_template.html.

Harris-Galveston Subsidence District, 2010, District regulatory plan 1999 [amended 2001, 2010]: 16 p., accessed March 7, 2011, at http://www.hgsubsidence.org/assets/ pdfdocuments/HGRegPlan.pdf.

Holzer, T.L., and Bluntzer, R.L., 1984, Land subsidence near oil and gas fields, Houston, Texas: Ground Water, v. 22, p. $450-459$.

Johnson, M.R., Ramage, J.K., and Kasmarek, M.C., 2011, Water-level altitudes 2011 and water-level changes in the Chicot, Evangeline, and Jasper aquifers and compaction 1973-2010 in the Chicot and Evangeline aquifers, HoustonGalveston region, Texas: U.S. Geological Survey Scientific Investigations Map 3174, 17 p., 16 sheets.

Kasmarek, M.C., 1997, Water-level altitudes in wells completed in the Chicot and Evangeline aquifers, Fort Bend County and adjacent areas, Texas, January-February 1990: U.S. Geological Survey Open-File Report 97-784, 2 sheets.

Kasmarek, M.C., Gabrysch, R.K., and Johnson, M.R., 2010, Estimated land-surface subsidence in Harris, Texas, 1915-17 to 2001: U.S. Geological Survey Scientific Investigations Map 3097, 2 sheets.

Kasmarek, M.C., and Houston, N.A., 2007, Water-level altitudes 2007 and water-level changes in the Chicot, Evangeline, and Jasper aquifers and compaction 19732006 in the Chicot and Evangeline aquifers, HoustonGalveston region, Texas: U.S. Geological Survey Scientific Investigations Map 2968, 159 p., 18 sheets.
Kasmarek, M.C., Houston, N.A., and Brown, D.W., 2006, Water-level altitudes 2006 and water-level changes in the Chicot, Evangeline, and Jasper aquifers and compaction 1973-2005 in the Chicot and Evangeline aquifers, HoustonGalveston region, Texas: U.S. Geological Survey Open-File Report 2006-1079, 15 sheets.

Kasmarek, M.C., Johnson, M.R., and Ramage, J.K., 2010, Water-level altitudes 2010 and water-level changes in the Chicot, Evangeline, and Jasper aquifers and compaction 1973-2009 in the Chicot and Evangeline aquifers, HoustonGalveston region, Texas: U.S. Geological Survey Scientific Investigations Map 3138, 17 p., 16 sheets, 1 appendix.

Kasmarek, M.C., and Lanning-Rush, Jennifer, 2004, Waterlevel altitudes 2004 and water-level changes in the Chicot, Evangeline, and Jasper aquifers and compaction 1973-2003 in the Chicot and Evangeline aquifers, Houston-Galveston region, Texas: U.S. Geological Survey Open-File Report 2004-1084, 13 sheets, accessed June 7, 2004, at http://pubs. usgs.gov/of/2004/1084/pdf/fig1.pdf.

Kasmarek, M.C., and Robinson, J.L., 2004, Hydrogeology and simulation of ground-water flow and land-surface subsidence in the northern part of the Gulf Coast aquifer system, Texas: U.S. Geological Survey Scientific Investigations Report 2004-5102, 111 p.

Lambeck, Kurt, Esat, T.M., and Potter, Emma-Kate, 2002, Links between climate and sea levels for the past three million years: Nature, v. 419, no. 6903, p. 199-206, accessed March 7, 2011, at http://www.nature.com/nature/ journal/v419/n6903/index.html.

Lone Star Groundwater Conservation District, 2011, Lone Star Groundwater Conservation District rules and bylaws: accessed March 7, 2011, at http:/www.lonestargcd.org/ management_plan.html.

National Oceanic and Atmospheric Administration, 2008, The elements of geodesy-The vertical datum: accessed March 7, 2011, at: http:/oceanservice.noaa.gov/education/kits/ geodesy/geo06_vertdatum.html.

National Oceanic and Atmospheric Administration, 2012, Tropical Storm Allison Heavy Rains and Floods Texas and Louisiana, June 2001:Accessed June 25, 2012 at: http:/www.nws.noaa.gov/os/assessments/pdfs/allison.pdf.

Pratt, W.E., and Johnson, D.W., 1926, Local subsidence of the Goose Creek oil field (Texas): Journal of Geology, v. 34, no. 7, p. 577-590.

Trahan, D.B., 1982, Monitoring local subsidence in areas of potential geopressured fluid withdrawal, southwestern Louisiana: Gulf Coast Association of Geological Societies Transactions, v. 32, p. 231-236. 
University of Texas, Bureau of Economic Geology, 1968, Geologic atlas of Texas, Beaumont sheet: Austin, scale $1: 250,000$.

University of Texas, Bureau of Economic Geology, 1974, Geologic atlas of Texas, Austin sheet: Austin, scale $1: 250,000$.

U.S. Army Corps of Engineers, 2006, Corpscon version 6: Topographic Engineering Center, Survey Engineering and Mapping Center of Expertise, accessed March 7, 2011, at http://www.agc.army.mil/corpscon/.

U.S. Geological Survey, 2011, National Water Information System-Web interface_-USGS water data for Texas: U.S. Geological Survey database, accessed March 7, 2011, at http://waterdata.usgs.gov/tx/nwis/nwis.
Wesselman, J.B., 1972, Ground-water resources of Fort Bend County, Texas: Texas Water Development Board Report $155,176 \mathrm{p}$.

Winslow, A.G., and Doyle, W.W., 1954, Land-surface subsidence and its relation to the withdrawal of ground water in the Houston-Galveston region, Texas: Economic Geology, v. 40, no. 4, p. 413-422, accessed March 7, 2011, at http://econgeol.geoscienceworld.org/cgi/ reprint/49/4/413.

Winslow, A.G., and Wood, L.A., 1959, Relation of land subsidence to ground-water withdrawals in the upper Gulf Coast region, Texas: Mining Engineering, Transactions of the American Institute of Mining, Metallurgical and Petroleum Engineers, Oct., v. 214, p. 1030-1034.

Worboys, M.F., 1995, GIS-A computer science perspective: London, Taylor and Francis, 376 p.

Publishing support provided by

Lafayette Publishing Service Center

Information regarding water resources in Texas is available at

http://tx.usgs.gov/ 


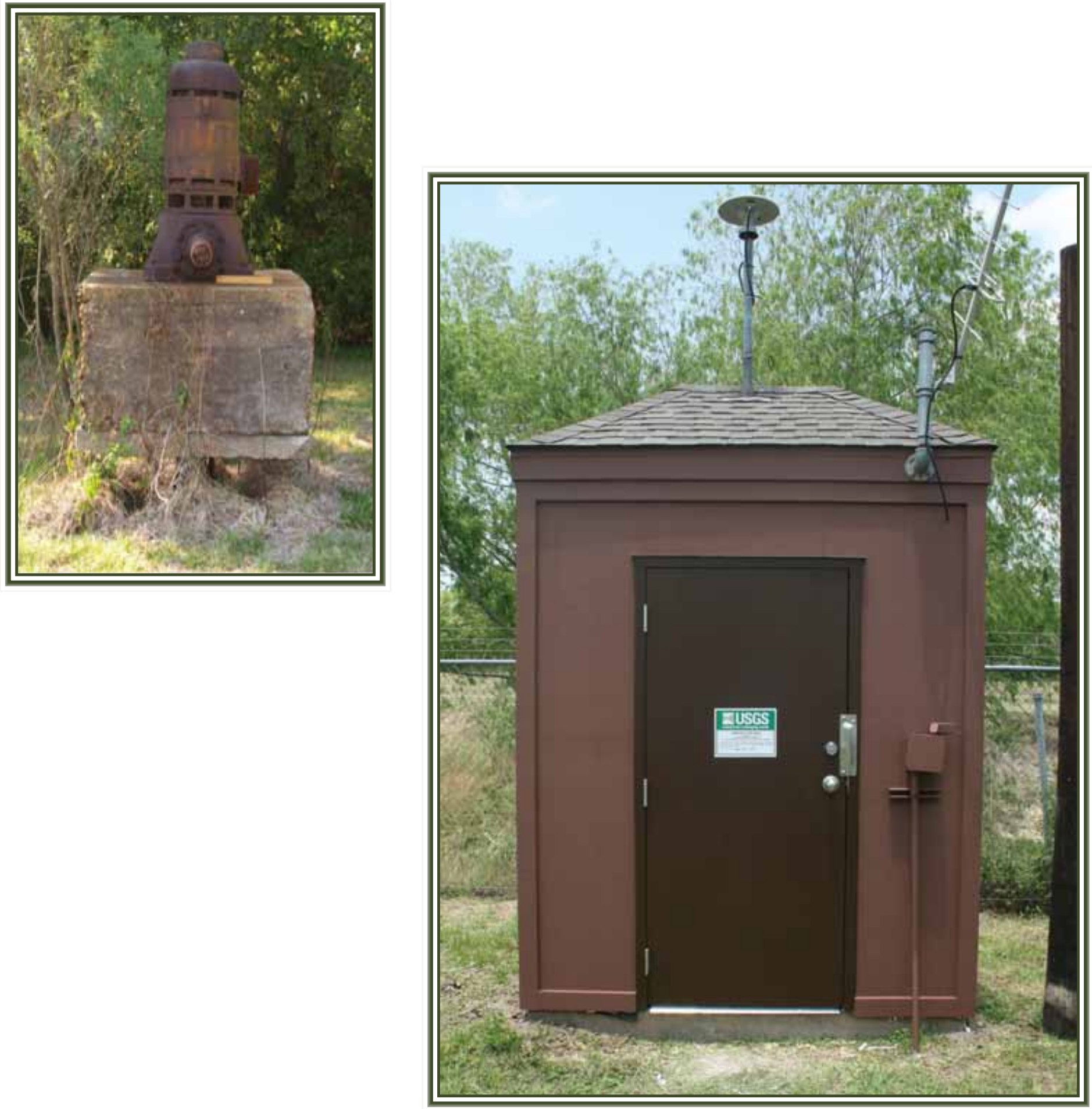

I SBN 978-1-4113-3451- 9

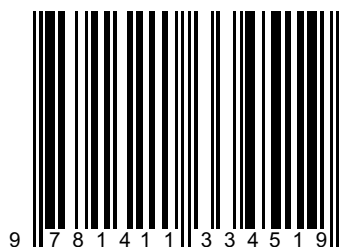

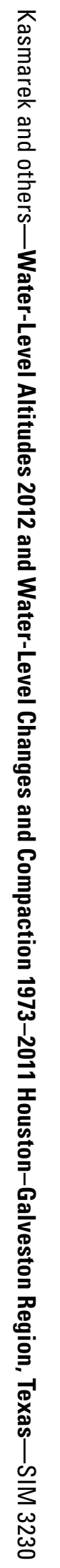

